USE OF A RAIMFALL-RUMOFF MODEL FOR SIMULATIMG EFFECTS OF FOREST MAMAGEMEMT OM STREAMFLOW IM THE EAST FORK LOBSTER CREEK BASIM, OREGOM

By Lenore Y. Makama and John C. Risley

U.S. GEOLOGICAL SURVEY

Water-Resource Investigations Report 93-4040

Prepared in cooperation with the

U.S. BUREAU OF LAMD MAMAGEMEMT

Portland, Oregon 


\section{U. S. DEPARTMENT OF THE INTERIOR BRUCE BABBITT, Secretary \\ U.S. GEOLOGICAL SURVEY \\ ROBERT M. HIRSCH, Acting Director}

For additional information write to:

District Chief

U.S. Geological Survey, WRD 10615 S.E. Cherry Blossom Drive Portland, Oregon 97216
Copies of this report can be purchased from:

U.S. Geological Survey

Earth Science Information Center

Open-File Reports Section

Box 25286, MS 517

Denver Federal Center

Denver, CO 80225 


\section{CONTENTS}

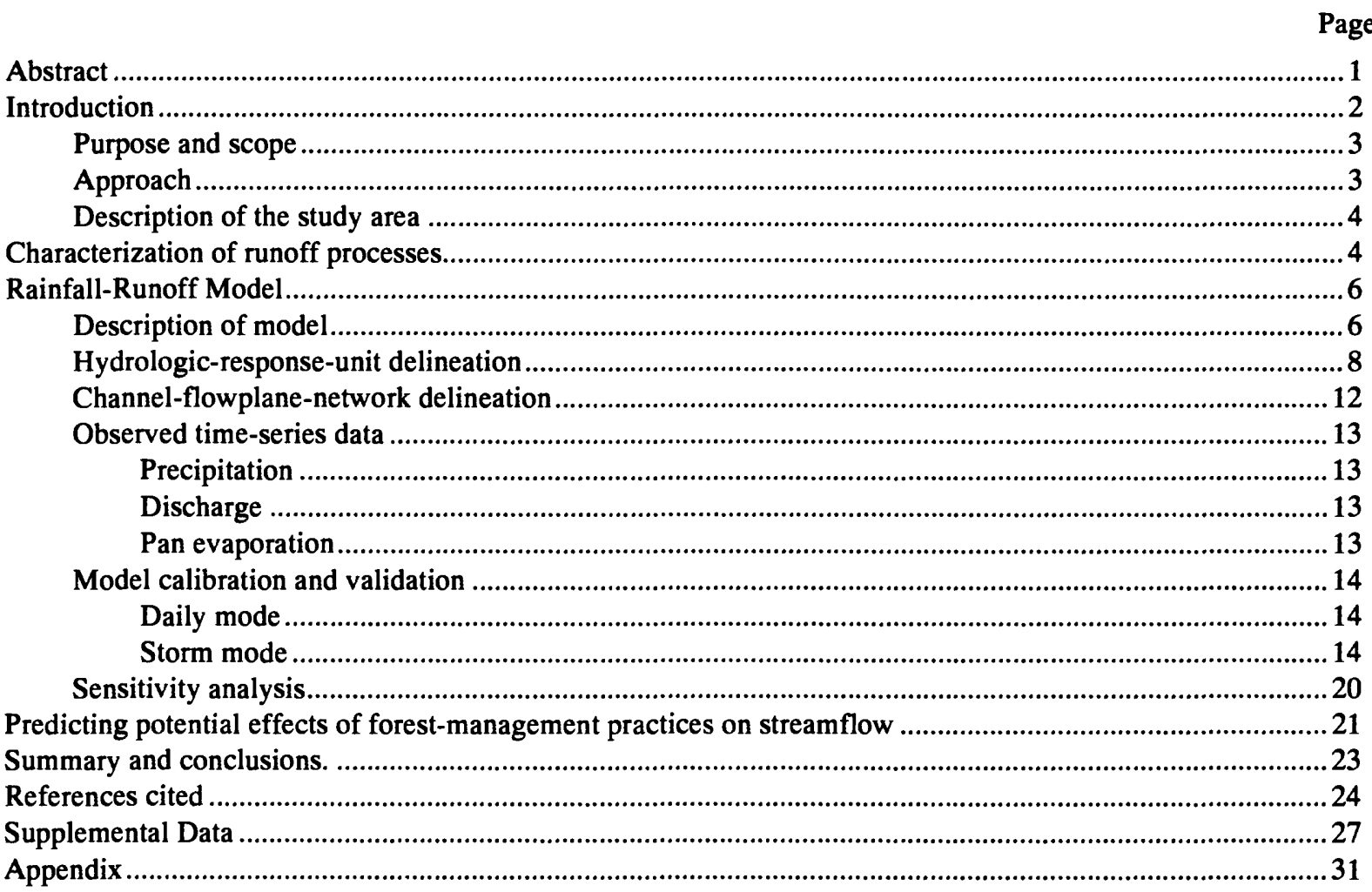

\section{ILLUSTRATIONS}

1. Map showing location of data-collection sites in East Fork Lobster Creek Basin ................................. 2

2. Graph showing observed discharge and precipitation with demonstrated lag times for East Fork Lobster Creek for storm period February 12-14, 1984 ............................................5

3. Schematic diagram of the Precipitation-Runoff Modeling System conceptual watershed model and its input, simplified to show the components used in the Oregon Coastal Basins Rainfall-Runoff Modeling Project...............................................................

4-7. Maps showing:

4. Hydrologic-response units for East Fork Lobster Creek Basin ................................................... 9

5. Surficial geology of East Fork Lobster Creek Basin .......................................................... 10

6. Vegetation units for East Fork Lobster Creek Basin............................................................. 11

7. Channel and overland flowplane network for East Fork Lobster Creek Basin .......................... 12

8-12. Graphs showing observed and simulated daily mean discharge (station 14306340), and precipitation, for East Fork Lobster Creek Basin:

8. October 1983 - September 1984

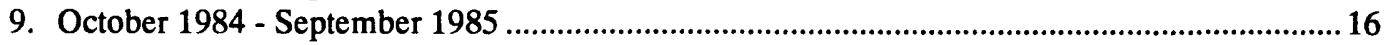

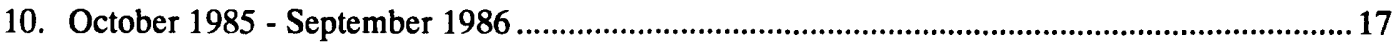

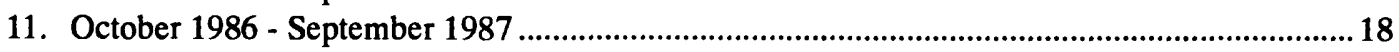

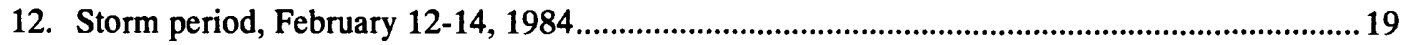




\section{TABLES}

TABLES

1. Physical characteristics of hydrologic-response units of the

East Fork Lobster Creek Basin ....

2. Statistical summary of observed and simulated discharge using Precipitation-Runoff Modeling System at U.S. Geological Survey

stream-gaging station 14306340

3. Changes in sensitivity of simulated discharge volumes in response to changes in

selected coefficients used in the Precipitation-Runoff Modeling System

4. Summary of Precipitation-Runoff Modeling System parameters adjusted during simulation of forest management.....

5. Physical characteristics of basins used in regional comparison

6. Simulated effects of forest management on selected streamflow characteristics using Precipitation-Runoff Modeling System calibrated to East Fork Lobster Creek Basin and observed changes following forest management in Alsea experimental basins ....

7. Definitions of Precipitation-Runoff Modeling System parameters 28

\section{CONVERSION FACTORS AND VERTICAL DATUM}

\begin{tabular}{lcc}
\hline \multicolumn{1}{c}{ Multiply } & By & To obtain \\
\hline & Length & millimeter \\
inch (in) & 25.4 & meter \\
foot (ft) & 0.3048 & square meter \\
AREA & & hectare (ha) \\
acre & 4,047 & hectare (ha) \\
acre & 0.407 & square kilometer $\left(\mathrm{km}^{2}\right)$ \\
square mile $\left(\mathrm{mi}^{2}\right)$ & 259.0 & 2.590 \\
square mile $\left(\mathrm{mi}^{2}\right)$ & & \\
\hline
\end{tabular}

Sea level: In this report "sea level" refers to the National Geodetic Vertical Datum of 1929-a geodetic datum derived from a general adjustment of the first-order level nets of both the United States and Canada, formerly called Sea Level Datum of 1929. 


\title{
Use of a Rainfall-Runoff Model for Simulating Effects of Forest Management on Streamflow in the East Fork Lobster Creek Basin, Oregon
}

\author{
By Lenore Y. Nakama and John C. Risley
}

Abstract

This report presents the results of a study by the U.S. Geological Survey, done in cooperation with the U.S. Bureau of Land Management, to evaluate the use of basin modeling for hydrologic assessment during formulation of forest-management plans. The Precipitation-Runoff Modeling System (PRMS), a deterministic, distributed-parameter, rainfall-runoff model, was applied to the East Fork Lobster Creek Basin in the Oregon Coast Range, to simulate the potential effects of timber harvesting on streamflow.

Calibration and validation were performed using the daily- and storm-mode versions of PRMS. Water years 1984 and 1985 were used for model calibration; and water years 1986 and 1987 were used for model validation. The model explained 87 percent of the total variation in observed discharge for the calibration period; mean error was less than 1 percent of mean observed discharge; and mean absolute error was 30 percent of mean observed discharge. Mean absolute errors in storm-discharge volumes and storm peaks were within 15 percent and 16 percent of observed means, respectively.

Selected subsurface- and ground-water-flow parameters were perturbed in a sensitivity analysis using the calibration period data to identify parameters exerting significant influence on streamflow processes. Decreasing the parameter values by 90 percent of their initial value results in a change in discharge volume ranging from minus 11 to plus 13 percent. Increasing the parameter values by 90 percent results in a change in discharge volume ranging from minus 10 to plus 3 percent.

The calibrated East Fork Lobster Creek Basin model was evaluated for hydrologic assessment in forest management through the simulation of two scenarios of increased clearcutting and increased road construction. Clearcutting the basin by 100 percent, concurrent with access roads covering 5 percent of the basin, increased total runoff by 8 percent and increased storm volume by 6 percent. No additional clearcutting, concurrent with access roads covering 12 percent of the basin, increased storm-peak magnitude by 14 percent. The simulation results compared favorably with the observed results of a nearby paired-basin study. 


\section{INTRODUCTION}

East Fork Lobster Creek drains a forested, headwater area coastside of the Coast Range of western Oregon (fig. 1). The primary use of the land has been allocated to intensive forest management for highsustained-yield timber production. Other land-use activities in the basin include enhancement of fish

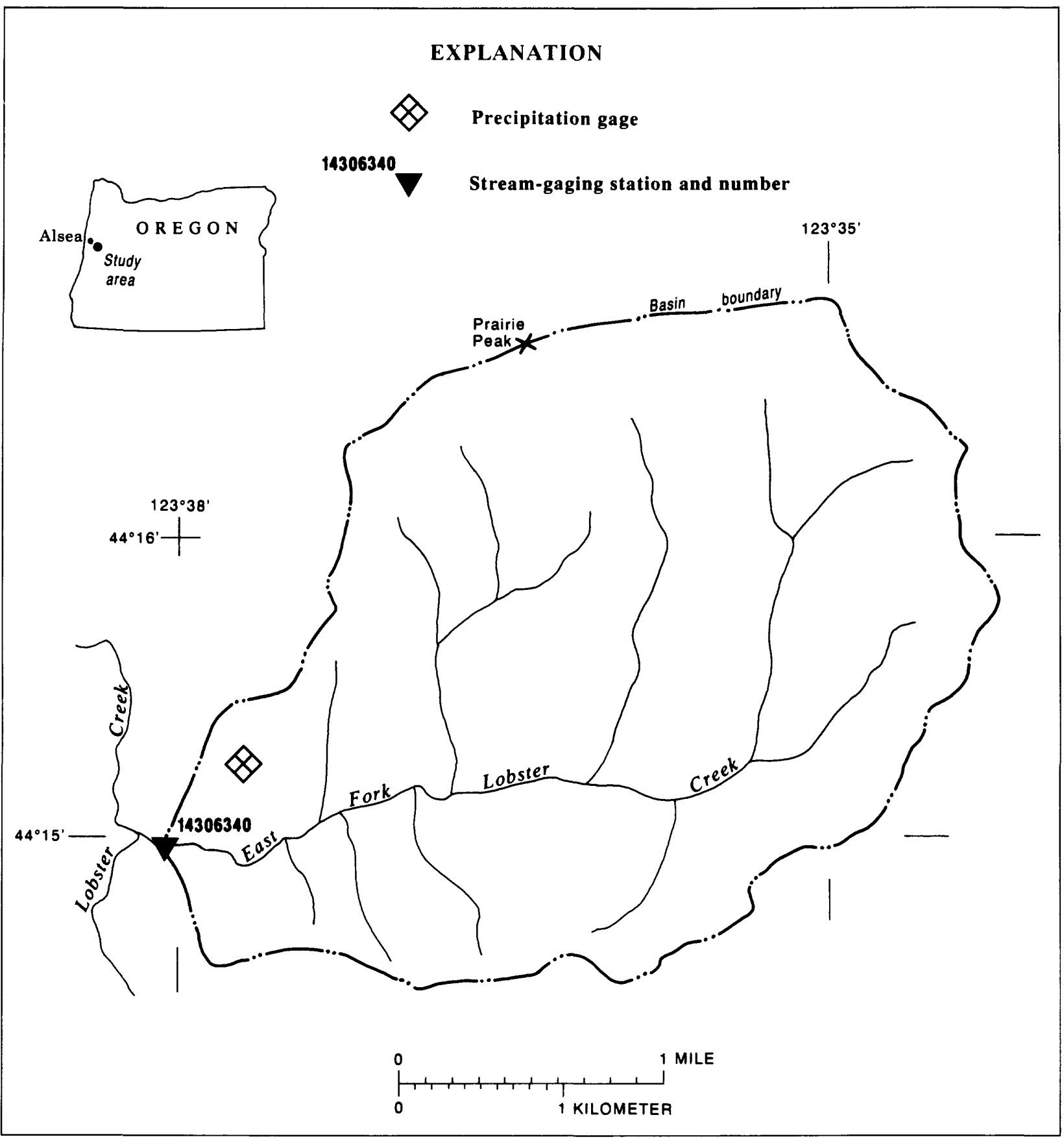

Figure 1.--Location of data-collection sites in East Fork Lobster Creek Basin. 
habitats and of riparian environments. Most of the basin is administered by the U.S. Bureau of Land Management (BLM), one of the Federal agencies responsible for planning, implementing, and evaluating management strategies for designated resource areas on public domain lands. An optimal resourcemanagement plan for the basin maximizes a sustained yield of timber production and minimizes the effect on existing environmental conditions. The optimal resource-management plan can be selected from a range of reasonable alternatives by quantifying the positive and negative effects on the basin for each plan.

Many of the analytical techniques and methods currently available for use in evaluating the effects of forest-management practices are limited with respect to their ability to provide (1) an increased physical understanding of streamflow generation and basin hydrology, (2) quantitative assessments of the hydrologic effects associated with proposed alternatives, and (3) a means of transferring results from gaged to ungaged areas. Basin modeling provides one method of addressing these problems.

Model parameters emulate the flux and storage of water in the surface, subsurface, and ground-water zones of the basin, providing an insight into the hydrologic processes governing flow characteristics. Through construction of a deterministic, distributed-parameter, rainfall-runoff model for gaged basins, runoff response to land-use alterations in a basin may be estimated, and model parameters can be transferred to ungaged basins having similar climatic and physical characteristics. This study of the East Fork Lobster Creek Basin is a cooperative effort between the U.S. Geological Survey (USGS) and the BLM. The objectives of the study were (1) to calibrate and validate a rainfall-runoff model for the East Fork Lobster Creek Basin and (2) to evaluate the use of the model as a predictive tool for assessing the effect of forest management on streamflow

\section{Purpose and Scope}

This report describes the results of model calibration and validation, and evaluates the extent to which runoff response to timber harvesting and increased road densities in East Fork Lobster Creek Basin can be simulated, using Precipitation-Runoff Modeling System (PRMS), a deterministic, distributed-parametermodeling system (Leavesley and others,1983).

\section{Approach}

The objectives of the study were met in a two-phase approach. The initial phase of activity involved model calibration. Existing precipitation data, streamflow data, and physical characteristics of the East Fork Lobster Creek Basin were analyzed to develop a conceptual understanding of the hydrologic processes and component interactions whose collective response results in streamflow generation. The conceptual model was then tested using PRMS. The model was calibrated to daily mean discharge and 30-minute stormdischarge data collected during the 1984 and 1985 water years at streamflow-gaging station 14306340. The model was validated using streamflow data collected during the 1986 and 1987 water years.

The second phase of the approach proceeded after the calibrated model provided a reasonable representation of the hydrologic environment. The model's simulated values were accepted as the best possible, given the quality of the existing data and availability of distributed catchment data. In the second phase, effects of timber-production activities on simulated discharge were estimated by imposing varying conditions of land-use modification on the basin. Model parameters used for the areas effected were adjusted to reflect land-use changes. Evaluation of the model's predictive capability for use in forest management was based on a comparison of results from the East Fork Lobster Creek simulations to observed data from a nearby paired-basin study. 


\section{Description of the Study Area}

East Fork Lobster Creek is located in the Coast Range physiographic division of western Oregon, approximately 7.8 miles to the south of Alsea (fig. 1). The creek is a third-order tributary to the Alsea River and drains a 5.71 square mile $\left(\mathrm{mi}^{2}\right)$ area above USGS stream-gaging station 14306340 . The basin is characterized by steeply-sloping uplands and deep, narrow valleys. Prairie Peak, rising to an elevation of 3,400 feet above sea level, is located on the northern boundary. Uplands at an elevation of approximately 2,200 feet define the eastern and southern limits of the basin. The elevation of the gaging station is 680 feet above sea level.

The region is under the influence of a marine climate and experiences pronounced seasonal variations in storm-precipitation quantity and intensity. Most of the annual precipitation falls between October and April. Winter storms, originating from frontal activity over the ocean and moving inland, may last for several days. Although snowstorms occasionally pass through, snowpack accumulation is an unusual occurrence. Generally convective, summer storms are relatively short in duration and have higher intensities than winter storms.

Two geologic units underlie the basin. Intrusive basalts are exposed in the uplands at elevations above 2,250 feet and underlie approximately 27 percent of the study area. The basalts contain abundant labradorite phenocrysts, augite, glass, and secondary minerals (Baldwin, 1955). At lower elevations, the Tyee Formation, composed of bedded feldspathic and micaceous sandstone and siltstone, is dominant (Wells and Peck, 1961).

The U.S. Soil Conservation Service (1973) has mapped eight different soil series in the study area. All soils in the basin have a high loam content, which is characteristic of most soils found in the Douglas fir region. Gravelly loams of the Bohannon and Slickrock soil series cover over 60 percent of the drainage area. Scattered units of Mulkey, Kilchis, Marty, Trask, Preacher, and Klickitat soil series are also present. Loams and gravelly clay loams compose about 11 and 14 percent, respectively, of the basin; rocky loams, 7 percent; and clay loams or silty clay loams, less than three percent. Colluvial and alluvial material, which occupies thin strips bordering stream channels, has been mapped in less than 1 percent of the area.

The land has been allocated primarily to intensive forest management, in order to produce a high sustained yield of timber. Clear-cut areas are replanted with Douglas fir. According to timber-unit maps supplied by the BLM, more than 80 percent of the area is predominantly Douglas fir. Red alder grows in narrow stands bordering stream banks, and the thin soils in the uplands of Prairie Peak primarily support grasses. Coverage densities vary with age and type of vegetation. Forest access roads of gravel and dirt are the only near-impervious or impervious surfaces in the basin, and roads cover approximately 2 percent of the total drainage area.

\section{CHARACTERIZATION OF RUNOFF PROCESSES}

Streamflow measured at the East Fork Lobster Creek gaging station is essentially flow routed to the stream channel by three flow components: surface, subsurface, and ground water. Observed streamflow represents the collective response of all storage and flow components, and the interactions among those components.

Insight into the probable paths by which moisture arrives at the gage can be ascertained by analyzing existing rainfall and streamflow records in relation to the physical characteristics of the basin. Examination of observed data from the East Fork Lobster Creek Basin gages indicates that the lag time, defined as the time difference between the center of mass of rainfall and the center of mass of the hydrograph, is between 3 and 10 hours, depending on antecedent-moisture conditions and rainfall intensities (fig. 2). 


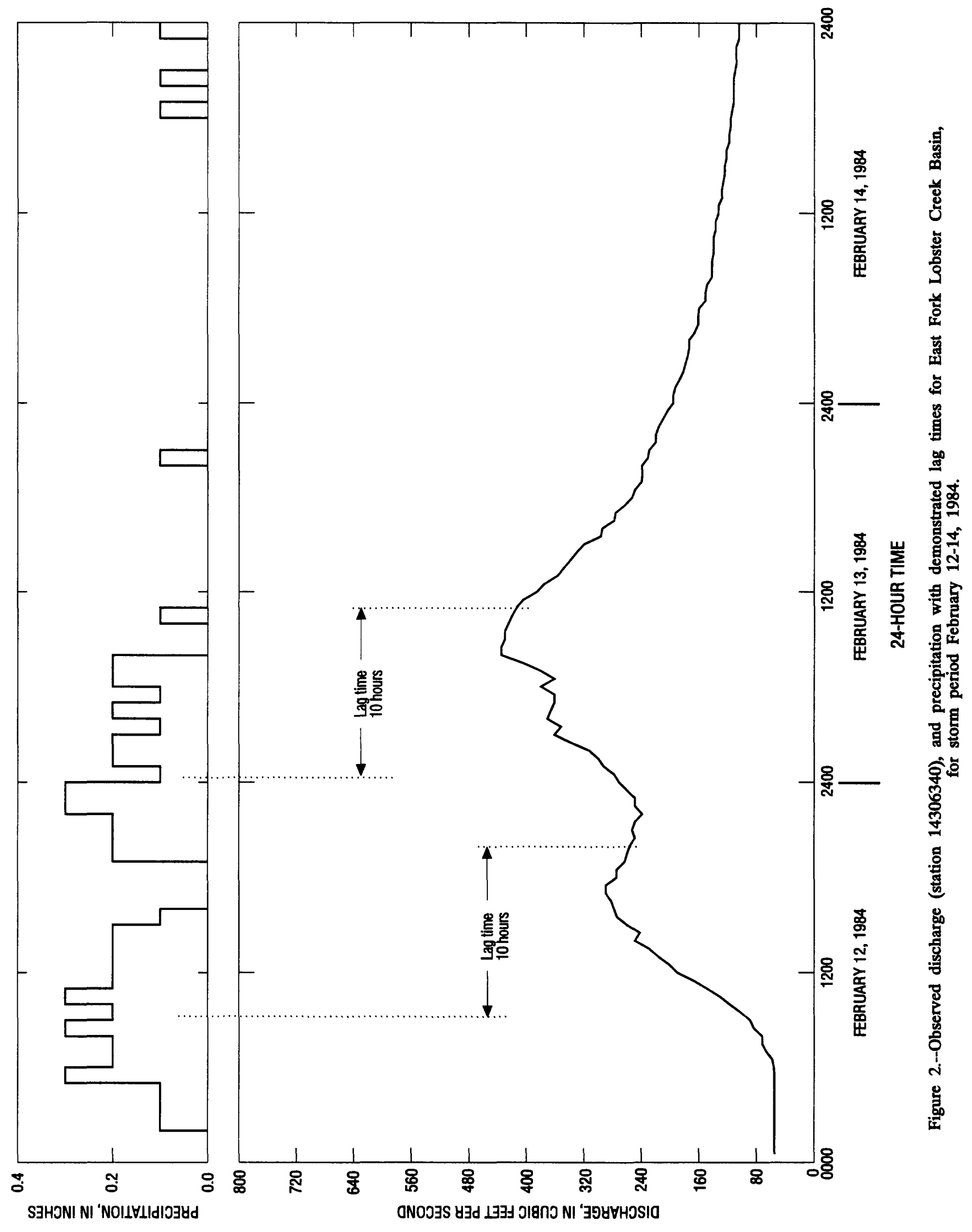


In general, rainfall amounts rarely exceed the infiltration capacity of Northwestern forest soils. The soils typically have a high loam and a high gravel content (U.S. Soil Conservation Service, 1973). The relatively high porosity and permeability values of the forest soils and the steep, highly dissected slopes that characterize the basin encourage subsurface flow contributions to streamflow. These values limit the occurrence of overland flow to impervious areas and to variable source areas that border stream channels which expand and contract in response to the intensity and duration of the particular storm (Fredriksen and Harr, 1979). Following analyses of soil, tensiometer, piezometer, and rainfall data, Harr (1979) evaluated water flux in soil and subsoil zones of a steep, forested slope in western Oregon. Harr (1979) concluded that subsurface flow and channel interception encompassed 97 and 3 percent, respectively, of storm flow. No overland flow was observed.

Regional data from wells penetrating the geologic units underlying the basin do not show ground water to be a major component of storm discharge (Schlicker and others, 1973). Analyses of well logs and aquifer tests indicate that the Tyee Formation generally has a low permeability with little water-storage capacity. The basalts that underlie the basin at higher elevations have similar water-bearing properties, although secondary fractures can provide efficient paths for flow (Baldwin, 1955). Flow derived from deep, underground systems is assumed to be dominant during the low-flow season. Baseflow, about $1 \mathrm{ft}^{3} / \mathrm{s}$ (cubic foot per second) on the average, sustains streamflow during the dry season.

\section{RAINFALL-RUNOFF MODEL}

The primary study objective was the application of a rainfall-runoff model to the East Fork Lobster Creek Basin. The procedures used in the application included an assessment of the required observed data, estimation of model parameters from basin characteristics, and model calibration and validation.

\section{Description of Model}

PRMS, a deterministic model capable of functioning as either a lumped- or distributedparameter-modeling system, was selected for this study. A moisture balance for each component of the hydrologic cycle is generated in a continuous simulation. PRMS was designed to evaluate the effects of various combinations of land-use activities and meteorological events on the hydrology and sediment yield of a basin.

PRMS can be operated in two modes - daily and storm. In the daily mode, model variables, including streamflow at the basin outlet, are simulated as daily mean and total values. In the storm mode, variables are simulated using a smaller user-defined time step which can vary from a minute to less than a day.

The basin is conceptualized as an interconnected series of reservoirs whose collective output produces the total system response (fig. 3). Gross precipitation is reduced by interception and becomes net precipitation. Streamflow is the sum of the various reservoir contributions. System inputs can include precipitation, air temperature, and solar radiation; the latter two drive the processes of evaporation, transpiration, snowmelt, and sublimation. In regions where snowpack does not form, air temperature or pan evaporation can be used to represent the energy input to the system.

The basin surface can be defined as pervious or impervious. Water enters the soil zone in the pervious areas as a result of precipitation and infiltration. The soil is viewed as a two-layered system.

Evapotranspiration losses deplete the upper or recharge zone which is user-defined by depth and waterstorage characteristics. Moisture in the lower zone, the depth of which is based on the rooting depth of the predominant vegetation, can be depleted only through transpiration. Surface retention of water on impervious zones is modeled as a reservoir. A maximum retention storage capacity for this zone must be satisfied before surface discharge can occur. When free of snow, the reservoir is depleted by evaporation. 


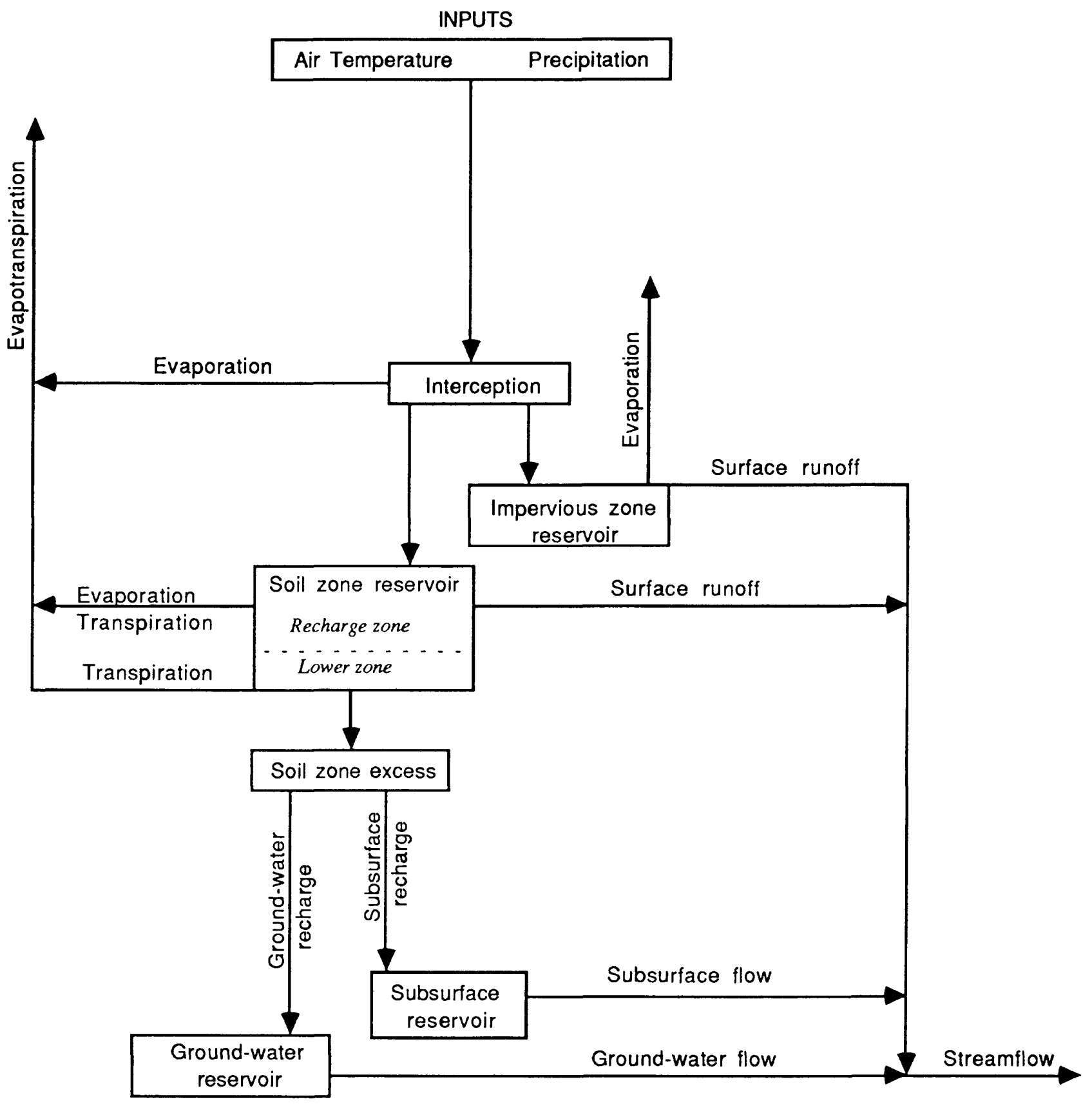

Figure 3.--Schematic diagram of the PRMS (Precipitation-Runoff Modeling System) conceptual watershed model and its input, simplified to show the components used in the Oregon Coastal Basins RainfallRunoff Modeling Project. Modified from Leavesley and others, 1983.

In the daily mode, surface runoff is computed using the contributing- or variable-source area approach. Surface runoff is related to a dynamic source area that expands and contracts according to rainfall characteristics and the capability of the soil mantle to store and transmit water (Troendle, 1985 p. 349). As conditions become wetter, the proportion of precipitation diverted to surface runoff increases, while the 
proportion that infiltrates to the soil zone and to the subsurface reservoir decreases. Daily infiltration (net precipitation less surface discharge) can be computed as either a linear or nonlinear function of antecedent-soil moisture and rainfall amount.

In the storm mode, surface runoff and infiltration for storm events are computed using a variation of the Green and Ampt equation (Green and Ampt, 1911) that allocates values of net rainfall reaching the soil surface to rainfall excess and infiltration, using either a user-specified time-step interval or 5-minute time-step interval, whichever is less. Surface runoff is then computed using the rainfall excess as input to the kinematic wave approximation to overland flow.

Input to the subsurface component is soil water in excess of field capacity. This excess moisture percolates to shallow ground-water components or moves downslope to some point of discharge above the water table. In the model, the rate of subsurface flow from this reservoir is computed using the storage volume of the reservoir and two user-defined routing coefficients.

The ground-water reservoir is defined as a linear system and is the source of baseflow. Recharge can originate from the soil zone (at field capacity) and from the subsurface reservoir. Contributions from the subsurface reservoir are computed daily as a function of a recharge-rate coefficient and the volume of water stored in the reservoir. Movement of ground water out of the system boundaries is accomplished by routing a portion of it to a ground-water sink.

Heterogeneity within the basin is accounted for by partitioning the basin into a number of units on the basis of slope, aspect, land use, soil type, geology, and precipitation distribution. Each unit is assumed to have a homogeneous hydrologic response and is called a hydrologic-response unit (HRU). A water balance and an energy balance are computed during each time step for each HRU and for the entire basin.

Partitioning provides the ability to impose land-use changes on part or all of the basin and to evaluate effects on selected HRU's and on the entire basin.

No channel routing is performed in the daily mode. In the storm mode, however, the basin can be partitioned into a series of interconnected flows and channel segments overlying the HRU's. Surface runoff is routed over flowplanes to a channel segment; channel flow is routed through the channel network. Channel and overland-flowplane routing use a finite-difference approximation of the continuity equation and the kinematic-wave approximation relating flow and the cross-sectional area of flow.

\section{Hydrologic-Response-Unit Delineation}

The basin was manually partitioned into five hydrologic-response units, using an overlay of maps containing information on geology, soil water-holding capacity, and vegetation in the basin (fig. 4).

The surficial geologic information was digitized from a geologic map of the area prepared by Baldwin (1955) [fig. 5]. Vegetation information was obtained from detailed-timber-unit maps provided by the BLM (fig. 6). No significant alteration in land use occurred during the 4 year period selected for the model. Landuse parameters, therefore, were assumed to have remained constant.

Additional heterogeneity within individual HRU's was resolved by taking an areally-weighted average. Parameters describing basin physiography, such as elevation, slope, and aspect, were estimated from 1:24,000-scale-series-topographic maps. Various characteristics of each HRU are listed in table 1. Other HRU parameter values, pertaining to various processes such as evaporation, interception, and infiltration for the final calibrated model are listed in the appendix. 


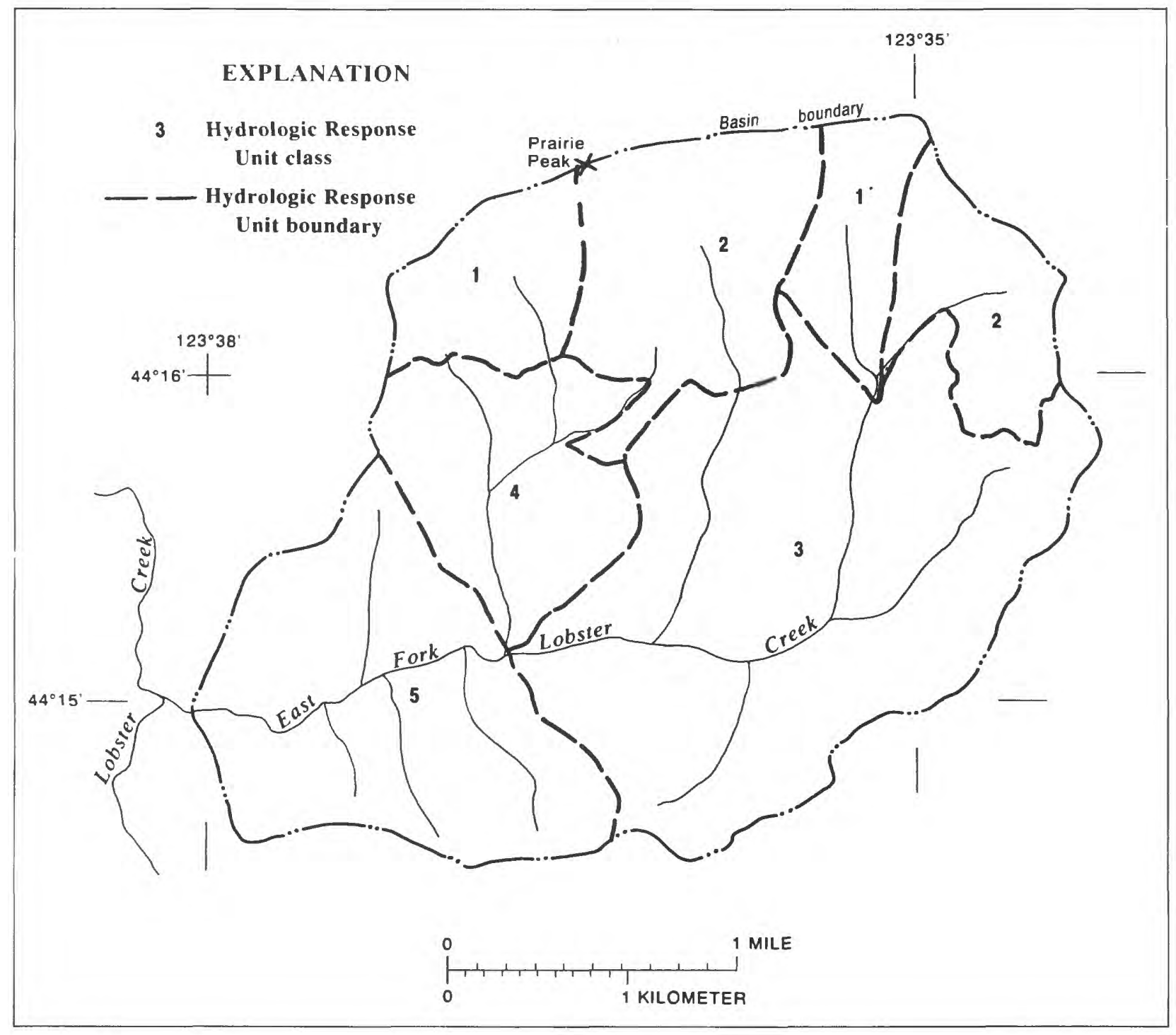

Figure 4.--Hydrogeologic-response units (HRU) for East Fork Lobster Creek Basin.

Table 1.-Physical characteristics of hydrologic-response units of the East Fork Lobster Creek Basin

\begin{tabular}{|c|c|c|c|c|c|}
\hline \multirow{2}{*}{$\begin{array}{l}\text { Hydrologic } \\
\text { response } \\
\text { unit }\end{array}$} & \multirow[b]{2}{*}{$\begin{array}{c}\text { Area } \\
\text { (acres) }\end{array}$} & \multirow{2}{*}{$\begin{array}{l}\text { Maximum soil } \\
\text { water-holding } \\
\text { capacity } \\
\text { (inches) }\end{array}$} & \multirow{2}{*}{$\begin{array}{c}\text { Effective } \\
\text { impervious } \\
\text { area } \\
\text { (percent) }\end{array}$} & \multicolumn{2}{|c|}{ Vegetation cover density } \\
\hline & & & & $\begin{array}{l}\text { Summer } \\
\text { (percent) }\end{array}$ & $\begin{array}{c}\text { Winter } \\
\text { (percent) }\end{array}$ \\
\hline 1 & 375 & 3.15 & 1 & 69 & 62 \\
\hline 2 & 730 & 3.80 & 4 & 75 & 69 \\
\hline 3 & 1,349 & 4.40 & 2 & 80 & 80 \\
\hline 4 & 395 & 4.10 & 3 & 71 & 71 \\
\hline 5 & 722 & 5.20 & 2 & 80 & 70 \\
\hline
\end{tabular}




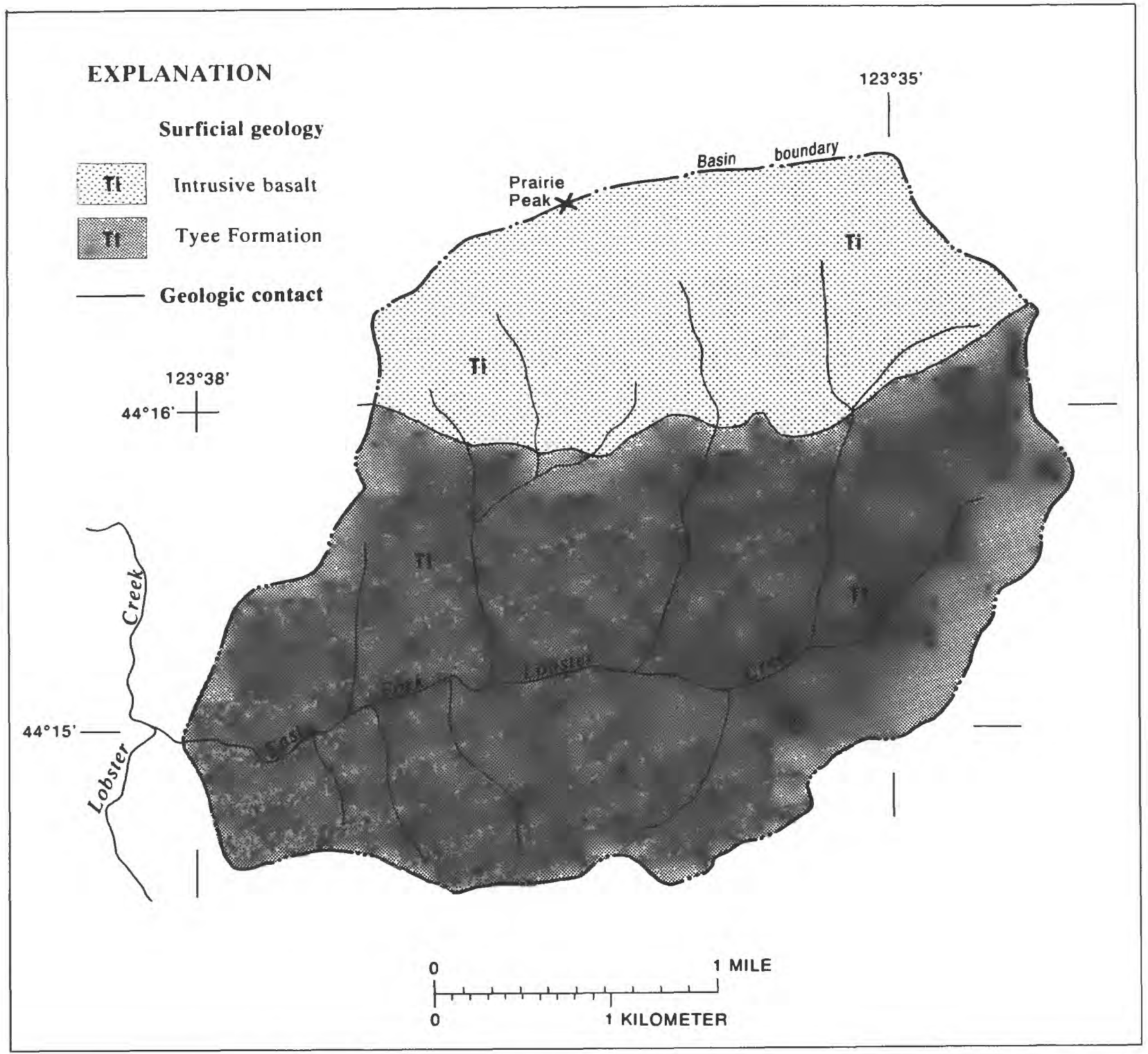

Figure 5.--Surficial geology of East Fork Lobster Creek Basin (from Baldwin, 1955). 


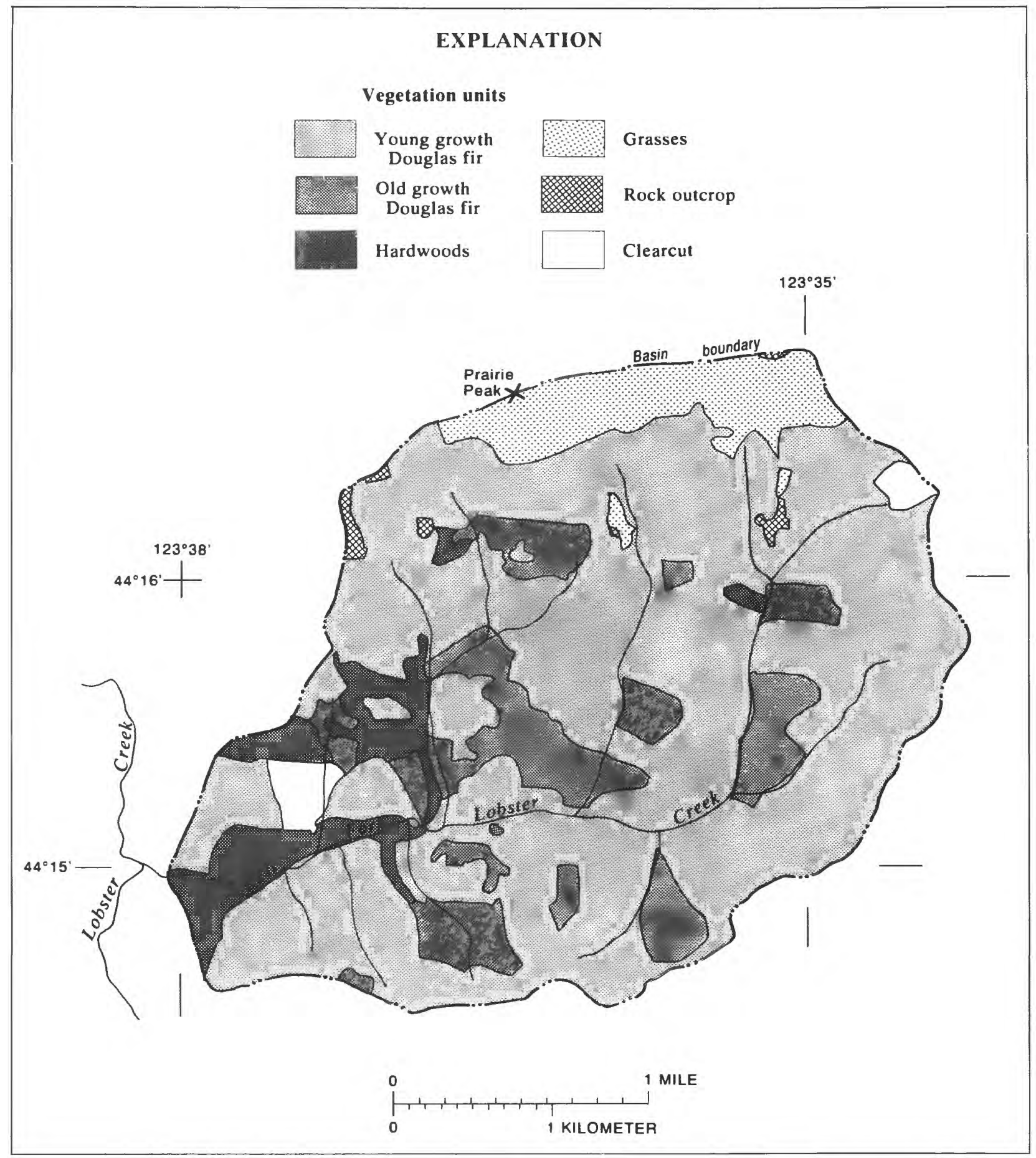

Figure 6.--Vegetation units for East Fork Lobster Creek Basin (from James Fogg, U.S. Bureau of Land Management, written communication, 1989). 


\section{Channel-Flowplane-Network Delineation}

In addition to HRU's, a channel-flowplane network is required for storm-mode simulation (fig. 7). The network is necessary for overland- and channel-flow routing during storms.

Channel segments in the network were based on prominent stream channels and some of the forest access roads. The routing effect of roads has been documented in various studies: Fredriksen and Harr (1979); Burroughs and others (1972); Harr (1983). Slow subsurface flow can be intercepted, transformed to overland flow, and transported rapidly through ditch-culvert systems to stream channels. A total of 14 channel segments represented the drainage network of the basin (of these, channel segments 1,4 , and 7 are road ditches). The slope and length of channels and roads were measured from USGS 1:24,000-scale-seriestopographic maps.

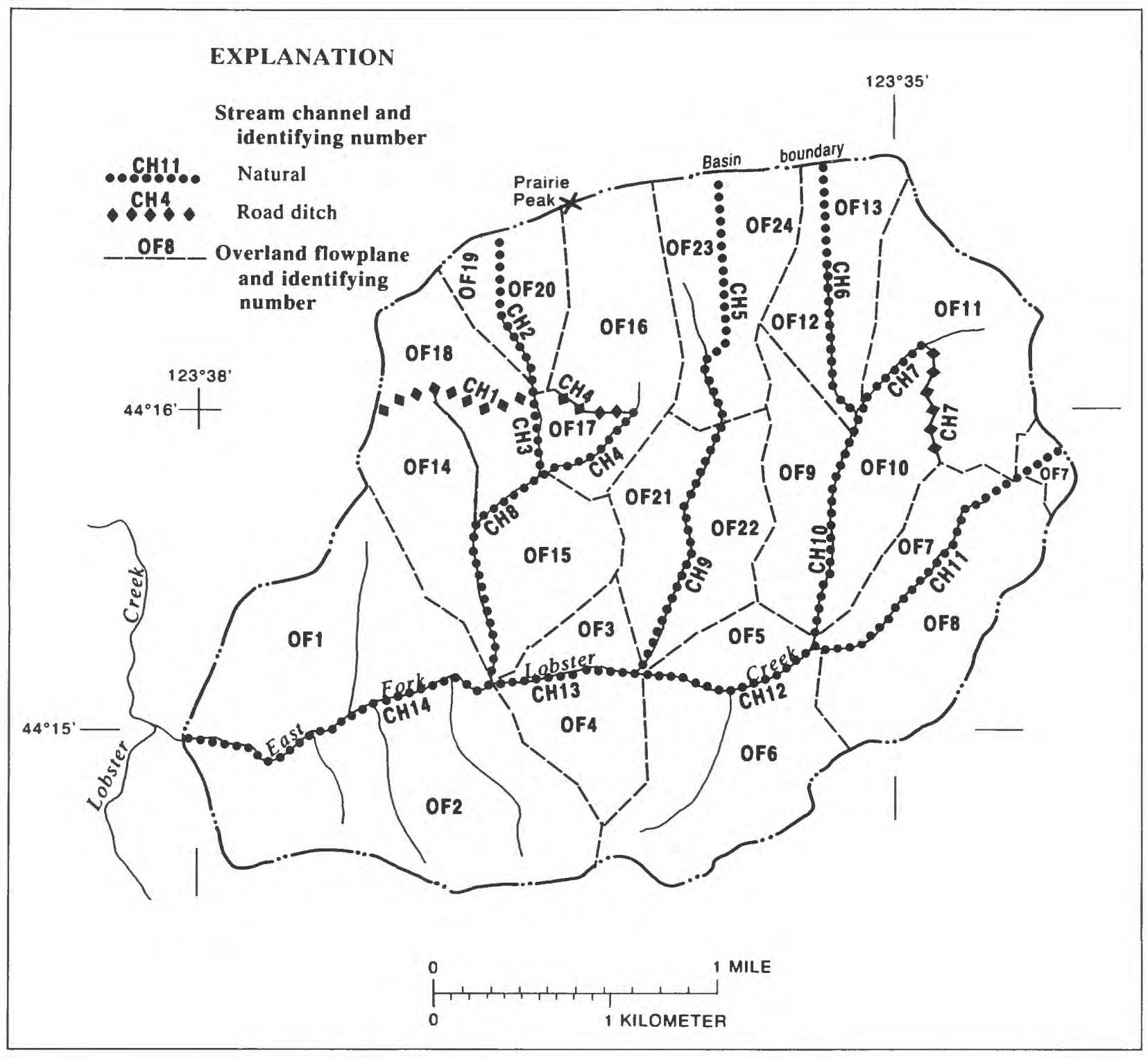

Figure 7.--Channel and overland flowplane network for East Fork Lobster Creek Basin. 
The channel segments were extended upward into the basin to form the boundaries of 24 flowplane units. The major criterion used in delineation of flowplane units was the general change in geologic, soil, and vegetative characteristics at higher elevations. Boundaries around flowplanes of similar characteristics corresponded to the five HRU's used for the simulations. Elevation data taken from U.S. Geological Survey 1:24,000-scale-series-topographic maps were used to calculate the mean elevation and slope of the flowplanes.

\section{Observed Time-Series Data}

The three types of observed time-series data used in the application of PRMS were precipitation, discharge, and pan evaporation.

\section{Precipitation}

Precipitation data were collected in the drainage basin approximately 1,100 feet above sea level near the western boundary of the basin (see fig. 1). A weighing-bucket gage, installed in 1983 by the BLM, recorded one-tenth-inch increments of precipitation on an hourly basis. On the basis of data collected at the site and at other rain-gage stations outside the study area, average annual precipitation for the region was estimated to be about 80 inches.

The degree to which the model is able to simulate observed streamflow is reduced by the uncertainties associated with measurement of the input data. Errors are introduced when precipitation measured at one point in the basin is extrapolated as an estimate of basin-wide precipitation. Average rainfall for the basin is most likely greater than measured rainfall because the average elevation of the basin is greater than that of the rain gage. Because data from only one rain gage were available for use during this study, the spatial distribution of rainfall on the basin remains largely unknown. Rainfall measurement errors at a point may range from several percent to 20 percent, depending on rainfall and wind conditions and gage exposure (Larson and Peck, 1974). In this study, the potential for deficiencies in gage-catch is relatively large because the rain gage which provided the input data was unshielded. During model calibration, discharge volumes and the HRU elevations and aspect provided the basis for identification of suitable correction factors with which to adjust the input data and to account for the effects of wind and orography.

\section{Discharge}

Daily mean and 30-minute-discharge data were collected at East Fork Lobster Creek near Alsea gaging station 14306340 according to standardized techniques of the USGS (Rantz, 1982). Complete records of daily streamflow are available in publications of the USGS. The pronounced seasonality exhibited in regional rainfall is reflected in the annual hydrograph. On the average, a large percentage of annual rainfall is received from November through March, during which time discharge volumes are correspondingly high. A gradual recession in streamflow occurs during late spring and summer. During the dry summer months, streamflow is sustained by baseflow of about $1 \mathrm{ft} / \mathrm{s}$. The time period selected for model testing provided a wide range of storm sizes on which to calibrate the model. On November 2, 1984, the maximum 24-hour rainfall in the calibration period occurred, resulting in the greatest daily mean and instantaneous peak flows recorded for the 1984 and 1985 water years. In response to 4.6 inches of rainfall, a daily mean discharge of $546 \mathrm{ft} 3 / \mathrm{s}$ and an instantaneous peak of $652 \mathrm{ft} 3 / \mathrm{s}$ were observed.

\section{Pan Evaporation}

Daily pan-evaporation data were measured in Corvallis, Oregon, at Oregon State University, approximately 10 miles northeast of the study area, and were considered the best available data for estimation of 
energy input to the system. The daily record of the data used during this study is available in publications of the U.S. National Oceanic and Atmospheric Administration (U.S. National Oceanic and Atmospheric Administration, 1983-87). All data were adjusted by a pan coefficient of 0.75 , which is commonly used in estimating evaporation loss from water bodies (Dunne and Leopold, 1978). Because the research on evapotranspiration losses in Northwestern forest is limited, water-body evaporation rates were used as a close approximation.

\section{Model Calibration and Validation}

The basin model was calibrated and validated using the daily and storm modes of PRMS. The calibration used daily mean streamflow data and 30-minute-streamflow data (for selected storm events) collected during the 1984 and 1985 water years at station 14306340. Streamflow data collected during the 1986 and 1987 water years were used to validate the model.

\section{Daily Mode}

During calibration, estimated parameters were adjusted within reasonable ranges until the best possible fit between observed and simulated discharge was achieved. Output from PRMS included a statistical summary describing the error between observed and simulated discharges. Parameters requiring the most adjustment during calibration were RCF and RCP in the subsurface component, and RCB, SEP, and RSEP in the ground-water component. A description of these and other PRMS parameters is given in table 7 at the back of the report. The final set of parameter values determined during the daily mode calibration is shown in the appendix. Plots of simulated and observed daily mean discharge and total daily rainfall for the calibration period (water years 1984 and 1985) are shown in figures 8 and 9. Similar plots for the validation period (water years 1986 and 1987) are shown in figures 10 and 11.

\section{Storm Mode}

Twelve storms, selected from the 1984 and 1985 water years, were used for the storm-mode calibration. The following two years provided seven storms used for validation of storm-mode parameters. For both periods, all storms producing an instantaneous peak flow of $110 \mathrm{ft}^{3} / \mathrm{s}$ or greater were modeled. Plots of simulated and observed half-hourly streamflow and half-hourly rainfall for a 3-day-storm period, from February 12 to February 14, 1984, are shown in figure 12. Using the storm-mode model for selected storms during the calibration period, the mean absolute error was 15 percent for storm volumes and 16 percent for storm-peak flows (table 2).

Soil parameters in the Green and Ampt (1911) infiltration equation included PSP and RGF. These parameters represented the range of the product of moisture deficit and capillary drive from field capacity to wilting point. Because of highly porous soils and slow rainfall conditions, it was assumed that nearly all rainfall on pervious areas infiltrated. The parameter for hydraulic conductivity (KSAT) was given a high value and the overland-flow routing option was turned off.

In the initial calibration, forest roads were modeled as only impervious areas. An alternate modeling strategy in which forest roads were modeled as stream channels was formulated and tested in a separate flow scenario. By treating forest roads that follow along topographic contours as stream channels, rather than impervious surfaces, storm-peak-error summaries indicated a better fit. On the average, 3 percent more of the variation between observed- and simulated-peak flows was explained. On the basis of the results of this analysis and on the physical plausibility of the routing effect of forest roads, all roads intercepting an overland flowplane were modeled as stream channels (fig. 7). The final set of parameter values determined during the storm-mode calibration is shown in the appendix. 


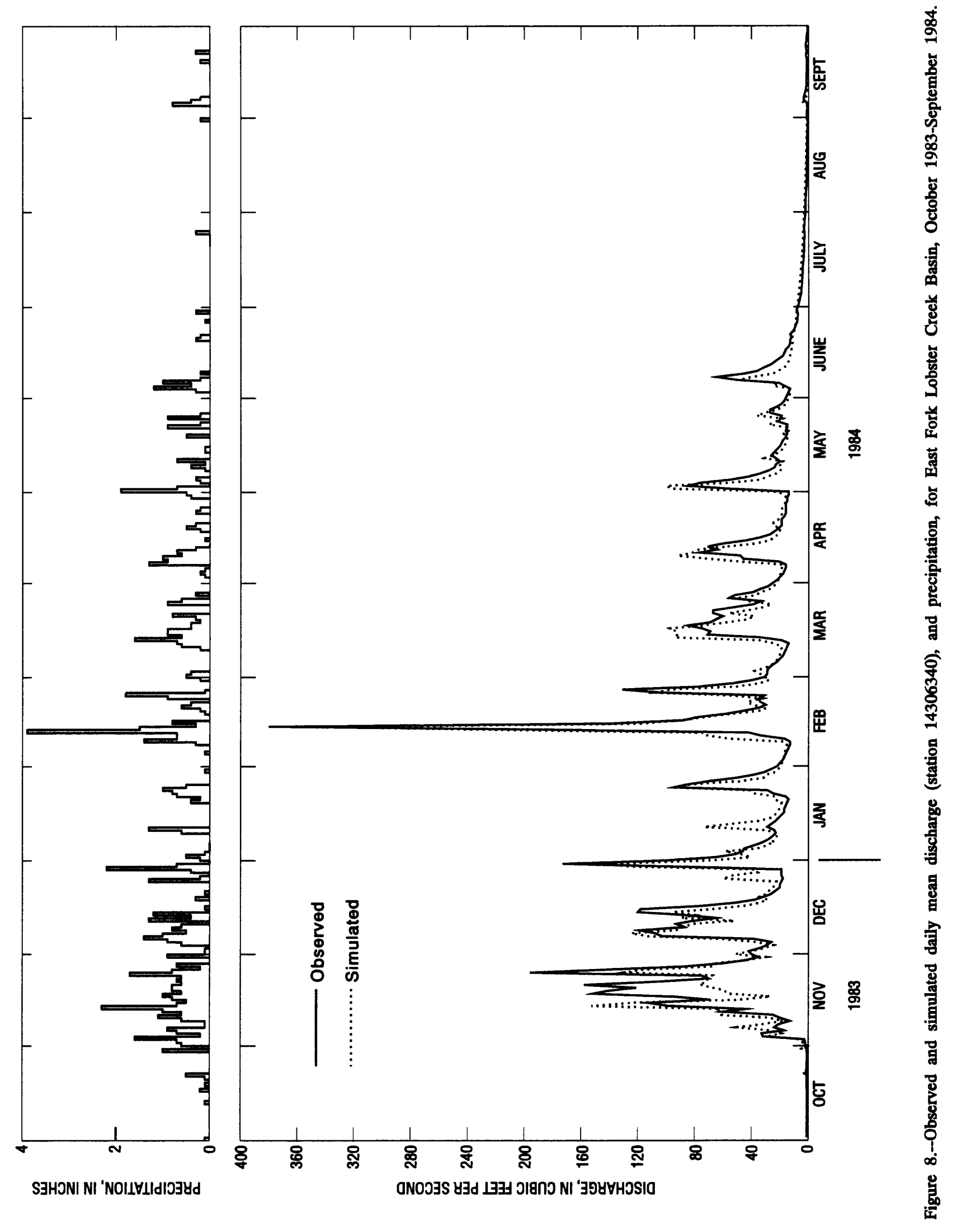




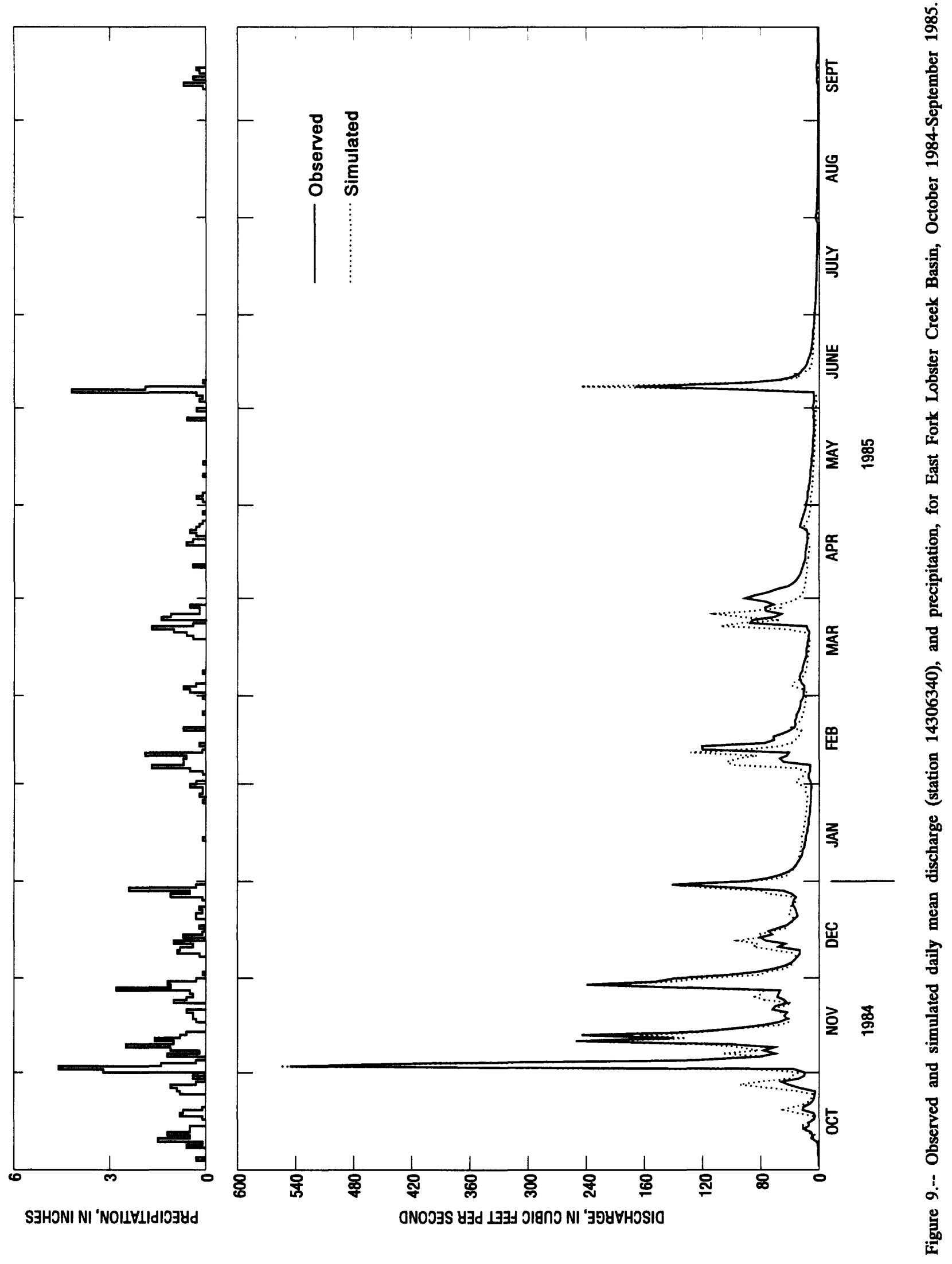




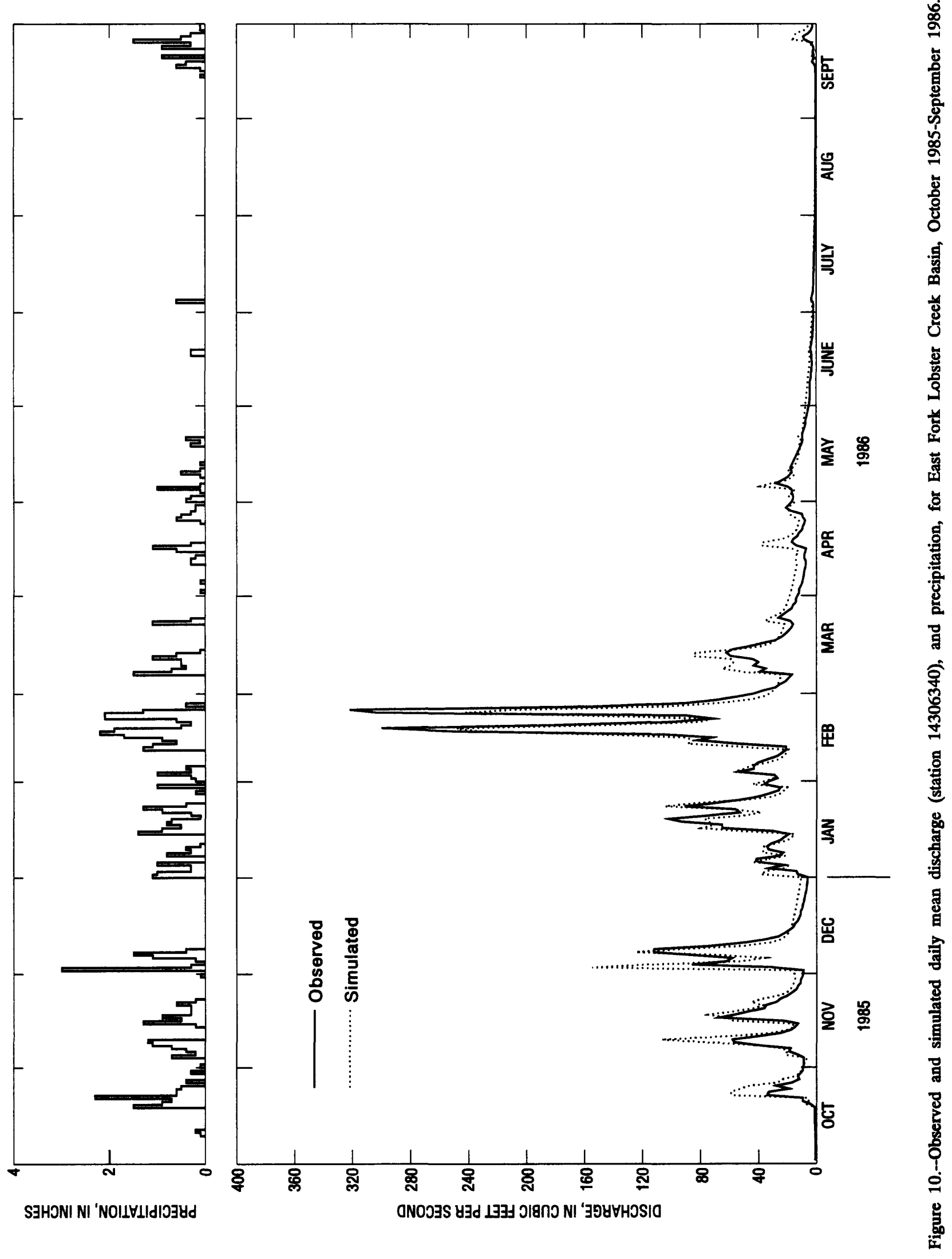




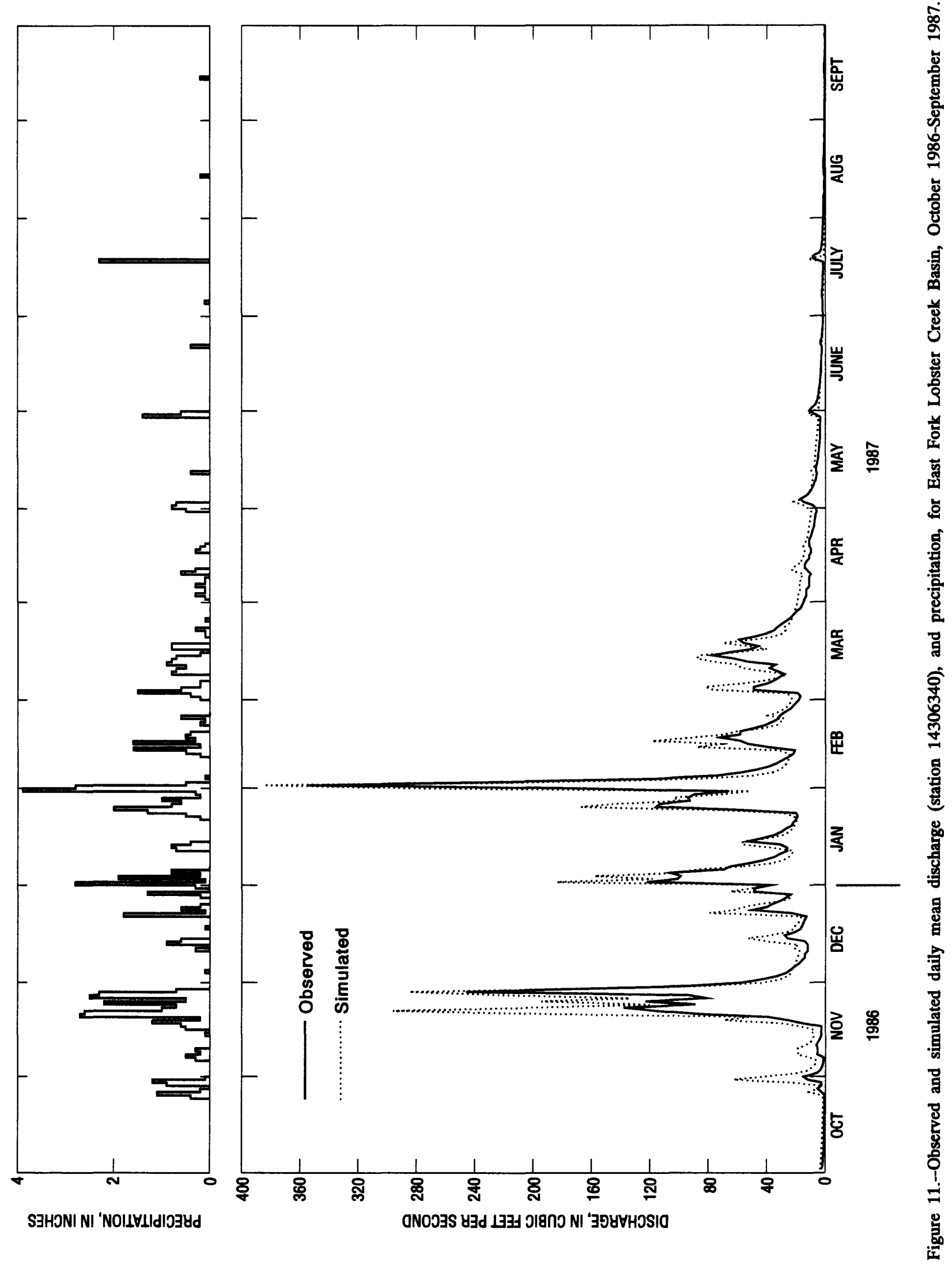




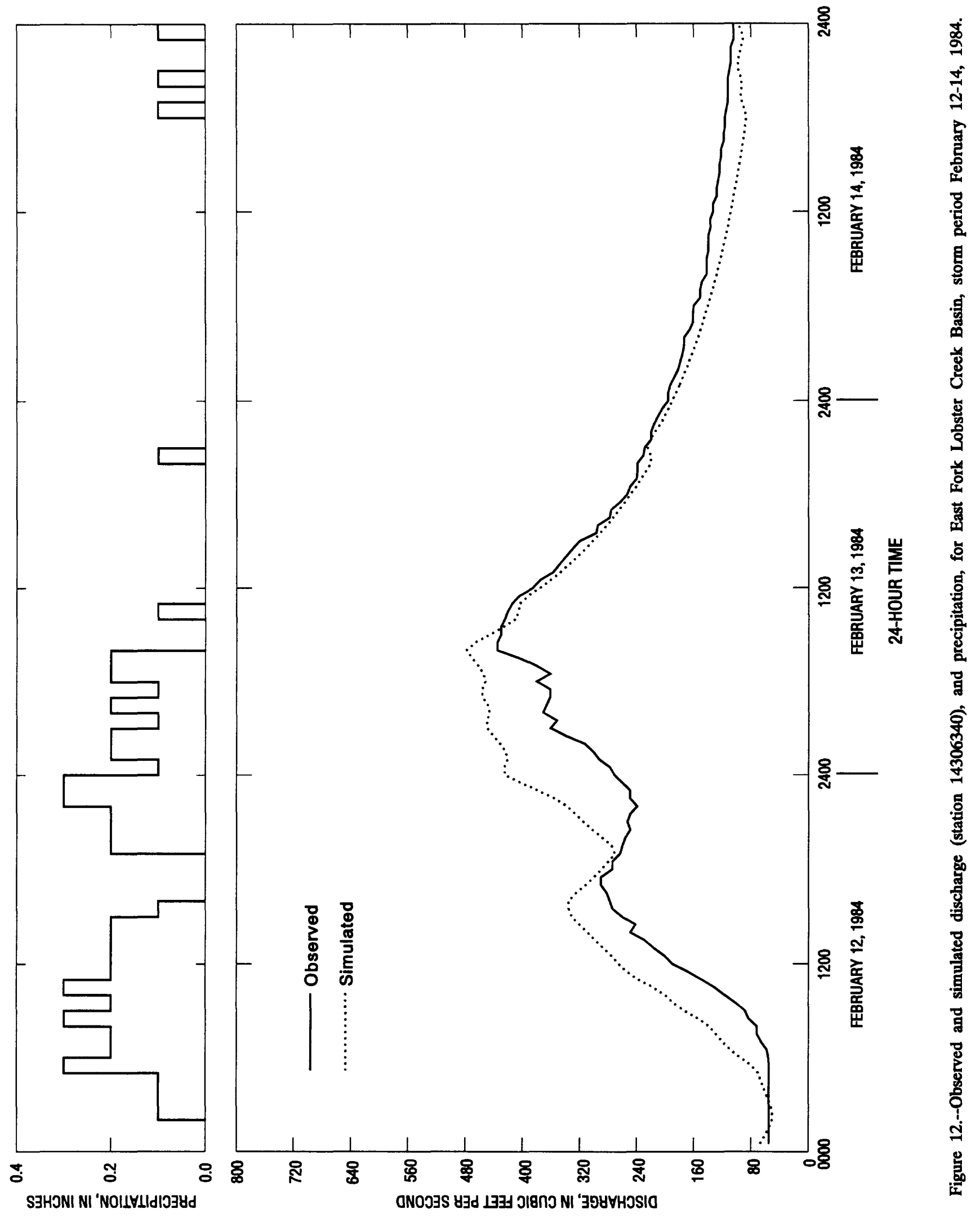


The performance of the model for the calibration and validation periods was evaluated using statistical results provided by PRMS output. These included a coefficient of determination defined as:

$$
\text { coefficient of determination }=1-\sum \mathrm{e}^{2} / \sum \mathrm{e}_{\mathrm{M}}^{2} \text {; }
$$

where

$$
\begin{aligned}
& e=O-P \\
& e_{M}=O-\bar{O} \\
& O=\text { observed runoff, } \\
& P=\text { predicted runoff, and } \\
& \bar{O}=\text { mean observed runoff for full period of simulation. }
\end{aligned}
$$

The coefficient of determination is equivalent to $R^{2}$ for regression analysis. Objective function values also were provided by PRMS as measures of error between observed and predicted runoff.

For the calibration period (water years 1984 and 1985) the daily model had a coefficient of determination of 87 percent. The mean error and mean-absolute error, expressed as a percentage of the mean-observed runoff, were 0.30 and 30 , respectively. A summary of these statistics for both the calibration and validation periods is given in table 2 .

Table 2.-Statistical summary of observed and simulated discharge using Precipitation-Runoff Modeling System at U.S. Geological Survey stream-gaging station 14306340

[Errors are expressed as a percentage of the observed mean values, $W Y=$ water year]

\begin{tabular}{lcc}
\hline Error statistic & $\begin{array}{c}\text { Calibration } \\
\text { period: } \\
1984-85 \text { WY }\end{array}$ & $\begin{array}{c}\text { Validation } \\
\text { period: } \\
1986-87 \text { WV }\end{array}$ \\
\hline Daily coefficient of determination & 0.87 & 0.83 \\
Monthly coefficient of determination & .98 & .92 \\
Percent mean error & .30 & -18 \\
Percent mean-absolute error & 30 & 31 \\
Percent mean-absolute-storm-volume error & 15 & 9 \\
Percent mean-absolute-storm-peak-error & 16 & 12 \\
\hline
\end{tabular}

\section{Sensitivity Analysis}

Selected subsurface- and ground-water-flow parameters were tested in a sensitivity analysis, to gain insights into model operation and to identify parameters that exert significant influence on streamflow processes. In the analysis, individual parameters were changed from plus or minus 20,50 , or 90 percent of their initial value, while all other parameters were held constant. RSEP is a coefficient used to compute seepage from the subsurface reservoir to the ground-water reservoir. GSNK is a coefficient used to compute seepage from the ground-water reservoir to a ground-water sink. RCB is a routing coefficient for the ground-water reservoir. RCF-RCP are routing coefficients for the subsurface reservoir. Table 3 contains a summary of sensitivity analysis showing the effect of changes in these parameter values on simulated discharge for the calibration period. Decreasing the parameter values by 90 percent of their initial value results in a change in discharge volume ranging from minus 32 to plus 18 percent. Increasing the parameter values by 90 percent results in a change in discharge volume ranging from minus 10 to plus 8 percent. 
Table 3.-Changes in sensitivity of simulated discharge volumes in response to changes in selected coefficients used in the Precipitation-Runoff Modeling System

[Capitalized abbreviations (see table 7 at back of report) are those used by Leavesley and others (1983)]

\begin{tabular}{|c|c|c|c|c|c|c|c|}
\hline \multirow{2}{*}{$\begin{array}{l}\text { Selected } \\
\text { coefficient }\end{array}$} & \multirow{2}{*}{$\begin{array}{l}\text { Initial } \\
\text { value }\end{array}$} & \multicolumn{6}{|c|}{$\begin{array}{l}\text { Percent change in simulated } \\
\text { discharge volumes corresponding } \\
\text { to percent change in selected coefficients }\end{array}$} \\
\hline & & .90 & -50 & -20 & +20 & +50 & +90 \\
\hline RSEP & 0.08 & +13 & +6 & +2 & -2 & -4 & -7 \\
\hline GSNK & .01 & +18 & +8 & +3 & -2 & -6 & -10 \\
\hline $\mathrm{RCB}$ & .02 & -32 & -11 & -3 & +3 & +5 & +8 \\
\hline RCF-RCP & $.02-.23$ & -11 & -4 & -1 & +1 & +2 & +3 \\
\hline
\end{tabular}

\section{PREDICTING POTENTIAL EFFECTS OF FOREST-MANAGEMENT PRACTICES ON STREAMFLOW}

Use of the model for hydrologic assessment in forest management was evaluated by imposing two conditions of land-use modification on the basin. Two hypothetical management scenarios were selected for simulation: (1) 100 percent clearcutting of the basin concurrent with forest access roads that cover 5 percent of the basin surface area, and (2) no additional clearcutting concurrent with forest access roads that cover 12 percent of the basin surface area. The potential effects of these hypothetical land-use changes on streamflow were estimated by substituting parameters describing forested areas with parameters describing either bare-soil areas or impervious surfaces. All parameters requiring adjustment were measurable characteristics of the basin. A summary of the parameters requiring adjustment is shown in table 4 . The assumption was made that because of the lack of data on soil and water processes in the study area, neither the infiltration capacities or the routing characteristics of the soils were affected. All of the calibrationperiod data were used in the storm mode for scenario simulations.

In general, timber-harvest activities in western Oregon basins have resulted in increased annual streamflow (Harris, 1973; Harr, 1976; Rothacher, 1970) and increased peak-flow magnitudes (Rothacher, 1973; Harr and others, 1975). Hydrologic effects associated with increased road densities include decreased infiltration rates on all or parts of the road and interception of subsurface flow by the road cut slope, allowing intercepted water to be routed more efficiently by ditch-culvert systems to the stream (Fredriksen and Harr, 1979).

Because no observed data reflecting the effects of posttreatment basin conditions from East Fork Lobster Creek were available for a direct assessment of the modeled response, the validity of model predictions was evaluated using observed changes documented in a paired-basin study in two nearby basins. Data obtained from experimental logging in the Needle Branch and Deer Creek Basins have been analyzed with respect to hydrologic effects in a number of previous reports (Harr and others, 1975; Harr, 1979; Harris, 1973 and 1977; Brown and Krygier, 1971). Comparisons incorporated in this report are based primarily on the findings of Harr and others (1975), Harr (1979), and Harris (1977). 
Table 4.-Summary of Precipitation-Runoff Modeling System parameters adjusted during simulation of forest management

\begin{tabular}{|c|c|}
\hline Parameter & Description \\
\hline COVDNS & Summer-cover density for major vegetation for each HRU \\
\hline COVDNW & Winter-cover density for major vegetation for each HRU \\
\hline ICOV & Predominant vegetation cover \\
\hline RNSTS & $\begin{array}{l}\text { Interception-storage capacity for unit area of vegetation for rain } \\
\text { during summer period, for each HRU }\end{array}$ \\
\hline RNSTW & $\begin{array}{l}\text { Interception-storage capacity for unit area of vegetation for rain } \\
\text { during winter period, for each HRU }\end{array}$ \\
\hline SMAX & Maximum available water-holding capacity of soil profile for each HRU \\
\hline REMX & Maximum available water-holding capacity of recharge zone for each HRU \\
\hline IMPERV & Effective impervious area as proportion of total HRU \\
\hline IMPV & Effective impervious area as proportion of total overland flowplane \\
\hline
\end{tabular}

The Needle Branch and Deer Creek Basins are approximately 25 miles northwest of East Fork Lobster Creek Basin. All three basins are located in the headwaters of the Alsea River drainage basin. Because the soils, geology, and land use occurring in the three basins are similar, the Needle Branch and Deer Creek data were considered adequate to evaluate the East Fork Lobster Creek model predictions. Table 5 contains a summary of physical characteristics for the three basins.

Table 5._Physical characteristics of basins used in regional comparison

\begin{tabular}{|c|c|c|c|c|c|c|}
\hline \multirow[b]{2}{*}{ Basins } & \multirow[b]{2}{*}{$\begin{array}{l}\text { Total area } \\
\text { (acres) }\end{array}$} & \multirow{2}{*}{$\begin{array}{l}\text { Gage } \\
\text { elevation } \\
\text { (feet) }\end{array}$} & \multicolumn{2}{|c|}{ Forest cover } & \multicolumn{2}{|c|}{ Predominant } \\
\hline & & & $\begin{array}{l}\text { Douglas fir } \\
\text { (percent) }\end{array}$ & $\begin{array}{c}\text { Alder } \\
\text { (percent) }\end{array}$ & $\begin{array}{c}\text { Geological } \\
\text { unit }\end{array}$ & $\begin{array}{l}\text { Soil } \\
\text { series }\end{array}$ \\
\hline $\begin{array}{l}\text { East Fork } \\
\text { Lobster Creek } \\
(14306340)\end{array}$ & 3,571 & 680 & 80 & 0 & Tyee Formation & $\begin{array}{l}\text { Bohannon/ } \\
\text { Slickrock }\end{array}$ \\
\hline $\begin{array}{l}\text { Needle Branch } \\
(14306700)\end{array}$ & 175 & 440 & 85 & 0 & Tyee Formation & $\begin{array}{l}\text { Bohannon/ } \\
\text { Slickrock }\end{array}$ \\
\hline $\begin{array}{l}\text { Deer Creek } \\
(14306810)\end{array}$ & 749 & 600 & 60 & 40 & Tyee Formation & $\begin{array}{l}\text { Bohannon/ } \\
\text { Slickrock }\end{array}$ \\
\hline
\end{tabular}

The hydrologic characteristics analyzed in the regional comparison included total runoff, storm volume, and storm peak. Results of the two simulated East Fork Lobster Creek Basin management scenarios and the observed responses from Needle Branch and Deer Creek Basins are summarized in table 6. Simulated responses of the East Fork Lobster Creek Basin are in general agreement with the observed responses of the other two basins. Based on application of the model to the management scenarios, increased clearcutting will result in increased total runoff and in storm volume. Increased road construction will result in increased storm-peak magnitude.

The relative magnitudes of the simulated responses are lower than the observed responses of Needle Branch and Deer Creek Basins. This may be explained, in part, by the assumption of negligible effect with respect to the routing characteristics of surface and subsurface zones. During simulation of the hypothetical 
conditions, no adjustments were made for parameters defining the characteristics of flow in these zones. Also, the East Fork Lobster Creek Basin is considerably larger $\left(5.71 \mathrm{mi}^{2}\right)$ than Needle Branch Basin $\left(0.27 \mathrm{mi}^{2}\right)$ and Deer Creek Basin $\left(1.17 \mathrm{mi}^{2}\right)$, which could indicate that the routing of land-surface disturbances in a basin can dampen their effect.

\begin{tabular}{|c|c|c|c|c|c|}
\hline \multirow[t]{2}{*}{ Location } & \multicolumn{2}{|c|}{ Watershed treatment } & \multicolumn{3}{|c|}{ Percent change } \\
\hline & $\begin{array}{c}\text { Percent } \\
\text { logged }\end{array}$ & $\begin{array}{l}\text { Percent } \\
\text { in roads }\end{array}$ & $\begin{array}{l}\text { Total } \\
\text { runoff }\end{array}$ & $\begin{array}{c}\text { Storm } \\
\text { volume }\end{array}$ & $\begin{array}{l}\text { Storm } \\
\text { peak }\end{array}$ \\
\hline \multicolumn{6}{|c|}{ East Fork Lobster Creek } \\
\hline Scenario 1 & 100 & 5 & +8 & +6 & 0 \\
\hline Scenario 2 & 0 & 12 & $\mathbf{0}$ & $\mathbf{0}$ & +14 \\
\hline Needle Branch & 87 & 5 & (1) +26 & $(1)+24$ & (1) +20 \\
\hline Deer Creek & 23 & 3 & $(1)+3$ & $(1)+2$ & $(1)+2$ \\
\hline
\end{tabular}

${ }^{1}$ Percent change as observed by Harris (1977)

\section{SUMMARY AND CONCLUSIONS}

The model constructed for the East Fork Lobster Creek Basin using PRMS, a deterministic, distributed-parameter, rainfall-runoff model, provided reasonable simulations of discharge at streamflow gaging station 14306340. Calibration and validation were performed on the basin model using both the daily- and storm-mode versions of PRMS. Water years 1984 and 1985 were used for model calibration; water years 1986 and 1987 were used for model validation. For the calibration period, the model explained 87 percent of the total variation in observed discharge; mean error was less than 1 percent of mean-observed discharge and mean-absolute error was within 30 percent of mean-observed discharge. Mean-absolute errors in storm-discharge volumes and storm peaks were within 15 percent and 16 percent of observed means.

Selected subsurface- and ground-water-flow parameters were perturbed in a sensitivity analysis using the calibration period data to identify parameters exerting significant influence on streamflow processes. Adjustments of plus or minus 90 percent of the RCB parameter resulted in the highest variation ( 40 percent) in the simulated discharge volumes. The same range of adjustment of the RCF-RCP parameters resulted in the lowest variation (14 percent).

The calibrated East Fork Lobster Creek Basin model was evaluated for hydrologic assessment in forest management through the simulation of two scenarios of increased clearcutting and increased road construction. Clearcutting the basin by 100 percent, concurrent with access roads covering 5 percent of the basin, increased total runoff by 8 percent and increased storm volume by 6 percent. No additional clearcutting concurrent with access roads covering 12 percent of the basin increased storm-peak magnitude by 14 percent. The simulation results compared favorably with the observed results of a nearby paired-basin study.

The results of this study indicate that rainfall-runoff modeling in managed areas of western Oregon can be used as a means of providing estimates of hydrologic effects for use during the formulation of forest-management plans. If used for the purposes of evaluating effects associated with management of alternatives, basin modeling can provide valuable guidance for the protection and enhancement of resource areas. 


\section{REFERENCES CITED}

Baldwin, Ewart M., 1955, Geology of the Mary's Peak and Alsea quadrangles, Oregon: U.S. Geological Survey Oil and Gas Investigations Map OM 162.

Brown, G.W., and Krygier, J.T., 1971, Clear-cut logging and sediment production in the Oregon Coast Range: Water Resources Research, v. 7, no. 5, p. 1189-1198.

Burroughs, E. R. Jr., Marsden, M. A., and Haupt, H. F., 1972, Volume of snowmelt intercepted by logging roads: Journal of the Irrigation and Drainage Division, ASCE, v. 98, no. 1R1, March 1972, p. 1-12.

Dunne, T., and Leopold, L.B., 1978, Water in environmental planning: San Francisco, W.H. Freeman and Company, 1st edition, P. 100-103.

Fredriksen, R. L., and Harr, R.D., 1979, Soil, vegetation, and watershed management, in Heilman, Paul E., Anderson, H. W., and Baumgartner, D. M., eds., Forest soils of the Douglas-fir region: Washington State University Cooperative Extension Service Report, p. 231-260.

Green, H.W., and Ampt, G.A., 1911, Studies of soil physics, 1--Flow of air and water through soils: Journal of Agricultural Research, v. 4, p. 1-24.

Harr, R. D., 1976, Hydrology of small forest streams in western Oregon: U.S. Forest Service General Technical Report PNW-55, $15 \mathrm{p}$.

---1979 , Hydrology of small forest streams in western Oregon: U.S. Forest Service General Technical Report PNW-55, $15 \mathrm{p}$.

---1983 , Effects of timber harvest on streamflow in the rain-dominated portion of the Pacific Northwest: Soil, Water and Fisheries Technology Transfer, Pacific Northwest Forest and Range Experiment Station, Corvallis, Oregon, $44 \mathrm{p}$.

Harr, R. D., Harper, W.C., Krygier, J.T., and Hsieh, F.S., 1975, Changes in storm hydrographs after roadbuilding and clearcutting in the Oregon Coast Range: Water Resources Research v. 11, no. 3, p 436-444.

Harris, D.D., 1973, Hydrologic changes after clear-cut logging in a small Oregon coastal watershed: Journal Research U.S. Geological Survey, v. 1, no. 4, p. 487-491.

- - -1977, Hydrologic changes after logging in two small Oregon coastal watersheds: U.S. Geological Survey Water-Supply Paper 2037, 31 p.

Larson, L.W., and Peck, E.L., 1974, Accuracy of precipitation measurements for hydrologic modeling: Water Resources Research, v. 10, no. 4, p. 857-863.

Leavesley, G.H., Lichty, R.W., Troutman, B.M., and Saindon, L.G., 1983, Precipitation-runoff modeling system; user's manual: U.S. Geological Survey Water-Resources lnvestigations Report 83-4238, 207 p.

Rantz, S.E., 1982, Measurement and computation of streamflow: Volume 1. Measurement of stage and discharge: U.S. Geological Survey Water-Supply Paper 2175, 284 p.

Rothacher, Jack, 1970, Increases in water yield following clear-cut logging in the Pacific Northwest: Water Resources Research, v. 6, no. 2, p. 653-658.

Rothacher, Jack, 1973, Does harvest in west slope Douglas-fir increase peak flow in small forest streams?: U.S. Forest Service Research Paper PNW-163, 13 p.

Schlicker, H.G., Deacon, R.J., Olcott, G.W., and Beaulieu, J.D., 1973, Environmental Geology of Lincoln County Oregon, Bulletin 81, State of Oregon, Department of Geology and Mineral Industries, $171 \mathrm{p}$.

Troendle, C.A., 1985, Variable source area models, in Anderson, M.G., and Burt, T.P., eds., Hydrological Forecasting: John Wiley and Sons Ltd., p. 347-403. 


\section{REFERENCES CITED-(Continued)}

U. S. National Oceanic and Atmospheric Administration, Climatological Data Oregon, October 1983 -

December 1983, v. 89, no. 10 - 12.

- - 1984, Climatological Data Oregon, January - December 1984, v. 90, no. 1 - 12.

- - -1985, Climatological Data Oregon, January - December 1985, v. 91, no. 1 - 12.

- - -1986, Climatological Data Oregon, January - December 1986, v. 92, no. 1 - 12.

- - -1987, Climatological Data Oregon, January - September 1987, v. 93, no. 1 - 9.

U.S. Soil Conservation Service, 1973, Soil survey of Alsea area, Oregon: U.S. Department of Agriculture,

Soil Conservation Service, 82 p. Agriculture, Soil Conservation Service, and U.S. Department of Interior, Bureau of Land Management, $82 \mathrm{p}$.

Wells, F.G., and Peck, D.L., 1961, Geologic map of Oregon west of the 121st meridian: U.S. Geological Survey Miscellaneous Geologic Investigations Map I-325. 
SUPPLEMENTAL DATA 
Table 7.-Definitions of Precipitation-Runoff Modeling System parameters

COVDNS

COVDNW

DRCOR

DRN

DTM

ELV

EVC

FLGTH

FRN

GSNK

GW

HRU

ICOV

IMPERV

IPET

IRU

ISOIL

ISSR1

ISUN

ITND

ITST

ITSW

KDS

KGW

KRES

KRSP

KSAT

LBC

NCRSEG

NDS

NDX

NGW

NIRU

NOFSEG

NRES

NRU

NS

NSP
Summer cover density for major vegetation for each hydrologic-response unit (decimal percent)

Winter cover density for major vegetation for each hydrologic-response unit (decimal percent)

Daily precipitation correction factor for rain for each hydrologic-response unit

Drainage factor for redistribution of saturated moisture storage as a fraction of KSAT-storm mode

Routing interval for overland flow or channel segment - storm mode (minutes)

Elevation of hydrologic-response unit (feet above MSL)

Evaporation pan coefficient for months 1-12

Length of overland flowplane or channel segment feet - storm mode

Roughness parameter for overland flowplane or channel segment-storm mode

Coefficient to compute seepage from each ground-water reservoir to a ground-water sink

Storage in each ground-water reservoir (acre - inches)

Hydrologic-response unit

Vegetation cover type for each hydrologic-response unit ( $0=$ bare, $1=$ grasses, $2=$ shrubs, $3=$ trees)

Percent impervious area for each hydrologic-response unit (decimal percent)

Potential evapotranspiration method switch $(0=$ Jensen-Haise, $1=$ Hamon, $2=$ use pan data)

Index for specific hydrologic-response unit

Soil type for each hydrologic-response unit (1=sand, 2=loam, 3=clay)

Surface runoff method switch ( $0=$ linear, $1=$ nonlinear)

Storm subsurface and ground-water routing switch

$0=$ not done, $1=$ subsurface and ground-water included in storm-mode computation)

Month that transpiration ends for each hydrologic-response unit

Month to begin checking for start of transpiration for each hydrologic-response unit

Transpiration switch for each hydrologic-response unit ( $0=$ vegetation dormant, $1=$ vegetation transpiring)

Index of rain gage associated with each hydrologic-response unit

Index of ground-water reservoir receiving seepage from each hydrologic-response unit

Index of subsurface reservoir receiving seepage from each hydrologic-response unit

Index of ground-water reservoir receiving seepage from each subsurface reservoir

Hydraulic conductivity of transmission zone - storm mode

I.D. of overland flowplane providing lateral inflow to channel segment-storm mode

Number of channel routing segments - storm mode

Number of rain gage sets

Number of intervals to subdivide overland flowplanes

Number of ground-water-storage reservoirs

Hydrologic-response unit associated with overland flowplane-storm mode

Number of overland flowplanes-storm mode

Number of subsurface storage reservoirs

Number of hydrologic-response units

Number of hydrograph segments in storm period-storm mode

Number of storm periods - storm mode 
Table 7.-Definitions of Precipitation-Runoff Modeling System parameters-Continued

PARM1

PCRID

PERV

PSP

RBA

RBC

$\mathrm{RCB}$

$\mathrm{RCF}$

$\mathrm{RCP}$

RECHR

REMX

RES

RESMX

RETIP

REXP

RGF

RNSTS

RNSTW

RSEP

RSTOR

SCN

SCX

$\mathrm{SC} 1$

SEP

SMAV

SMAX

THRES

TYPE

UPCOR

UP1

UP2

UP3
Kinematic parameter alpha for plane or channel type $=4$; or width of channel for channel type $=1$ or 3 -storm mode

Identification characters for overland flowplanes, channel and reservoir segments and junctions - storm mode

Percent of pervious area on each hydrologic-response unit (decimal)

Combined effect of moisture deficit and capillary potential (inches) - storm mode

Index of overland flow segment to be used as input to channel segment - storm mode

Identification of overland flowplane providing lateral inflow to channel segment - storm mode

Routing coefficient for each ground-water reservoir

Linear routing coefficient for each subsurface reservoir

Nonlinear routing coefficient for each subsurface reservoir

Storage in upper part of soil profile where losses occur as evaporation and transpiration (inches)

Maximum value of RECHR for each hydrologic-response unit (inches)

Storage in each subsurface reservoir (acre - inches)

Coefficient for routing water from each subsurface reservoir to ground-water reservoir

Maximum retention storage on impervious area for each hydrologic-response unit (inches)

Coefficient for routing water from each subsurface reservoir to ground-water reservoir

Ratio of combined effects of moisture deficit and capillary potential at wetting front from wilting point to field capacity - storm mode

Interception storage capacity of unit area of vegetation for rain during summer period, for each hydrologic-response unit (inches)

Interception storage capacity of unit area of vegetation for rain (inches) during winter period, for each hydrologic-response unit

Seepage rate from each subsurface reservoir to ground-water reservoir (inches per day)

Retention storage on impervious area for each hydrologic-response unit

Minimum contributing area for surface runoff when $1 S S R 1=0$; coefficient in contributing area - soil moisture index relation when SSR1=1

Maximum possible contributing area for surface runoff as proportion of each hydrologic-response unit Coefficient in surface runoff contributing area - soil moisture index relation

Seepage rate from soil moisture excess to each ground-water reservoir (inches per day)

Daily available water in soil profile for each hydrologic-response unit (inches)

Maximum available water holding capacity of soil profile for each hydrologic-response unit (inches)

Minimum depth of flow for continuation of routing (feet)-storm mode

Type of overland flowplane or channel-routing segment-storm mode

Storm precipitation correction factor for each hydrologic-response unit

Upstream inflow segment for channel-routing segment-storm mode

Upstream inflow segment for channel-routing segment-storm mode

Upstream inflow segment for channel-routing segment-storm mode 
30 
APPENDIX: PRMS daily-and storm-mode output showing final parameter values from the calibration period 


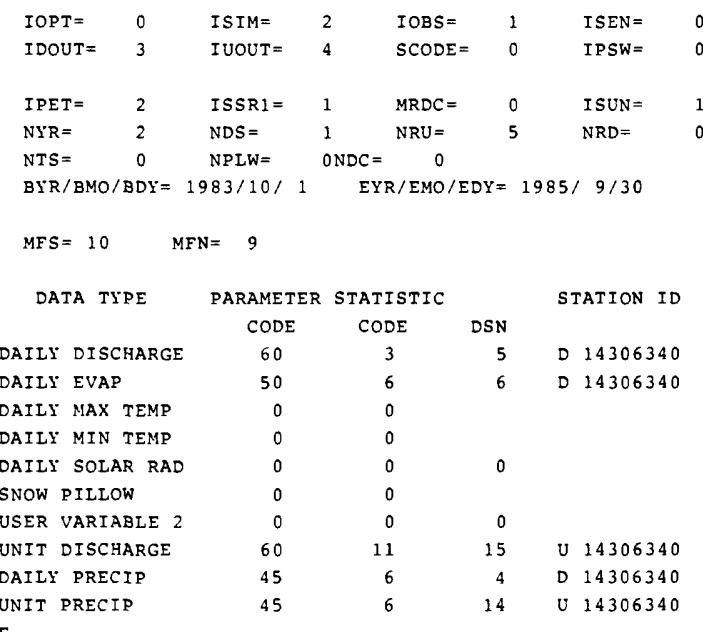

IE

RMXA $=0.80 \quad$ RMXM $=0.60 \quad$ MTSS $=0 \quad$ MTSE $=0 \quad$ ARSA $=0.05 \quad$ ARSM $=0.20$

$\operatorname{CSEL}(1-5)=$

MPCS $=7 \quad \mathrm{MPCN}=9 \quad \mathrm{MPC1}=0 \quad$ PCONR $=1.00 \quad$ PCONS $=1.00$

$\operatorname{PCR}(1-\mathrm{NRU})-\quad 1.10 \quad 1.10 \quad 1.10 \quad 1.10 \quad 1.10$

PCS(1-NRU) - $\quad 1.10 \quad 1.10 \quad 1.10 \quad 1.10 \quad 1.10$

$\operatorname{CTS}(1-12)=0.000000 \quad 0.000000 \quad 0.000000 \quad 0.000000 \quad 0.000000 \quad 0.000000 \quad 0.000000 \quad 0.000000 \quad 0.000000 \quad 0.000000 \quad 0.000000 \quad 0.000000$ $\mathrm{CTW}=\quad 0.00$

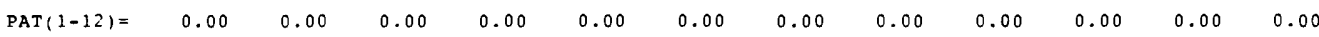

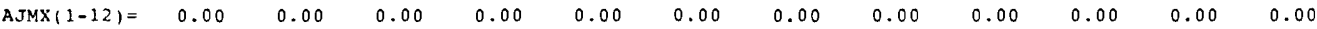

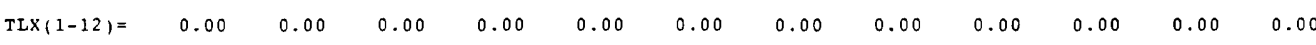

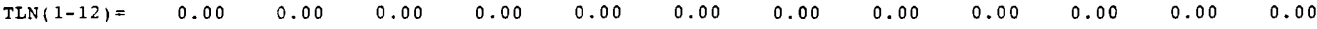

$\operatorname{EVC}(1-12)=\quad \begin{array}{llllllllllll}0.750 & 0.750 & 0.750 & 0.750 & 0.750 & 0.750 & 0.750 & 0.750 & 0.750 & 0.750 & 0.750 & 0.750\end{array}$

$I S P 1=0 \quad I S P 2=0 \quad$ EAIR $=1.000 \quad$ FWCAP $=1.00 \quad$ DENI $=1.00 \quad$ DENMX $=1.00 \quad$ SETCON $=1.00 \quad$ BST $=0.00$

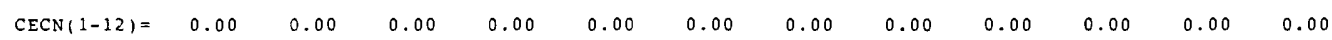

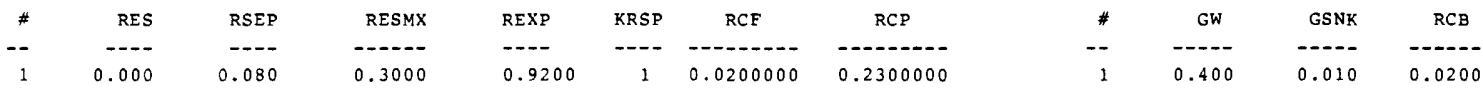




\begin{tabular}{|c|c|c|c|c|c|c|c|c|c|c|c|c|c|c|c|c|c|}
\hline \multirow[t]{3}{*}{ IRU } & IRD & ITST & ITSW & TXAJ & RNSTS & SNST & COVDS & ICOV & SMAX & REMX & $\mathrm{SCN}$ & SRX & \multicolumn{2}{|c|}{ RETIP } & SEP & \multicolumn{2}{|c|}{ KRES } \\
\hline & $-\cdots$ & $\cdots$ & --- & $=-$ & $-\cdots$ & --- & $\cdots$ & ---- & $\cdots$ & --- & -- & --- & \multicolumn{2}{|r|}{----} & $-\cdots$ & \multicolumn{2}{|c|}{$-\ldots$} \\
\hline & ELEV & ITND & СтX & TNAJ & RNSTW & TRNCF & COVDW & ISOIL & SMAV & RECHR & $\mathrm{Sc} 1$ & $\operatorname{scx}$ & & IMPRV & KSTOR & \multicolumn{2}{|c|}{ KGW } \\
\hline \multirow[t]{2}{*}{1} & 0 & 4 & 1 & 0.00 & 0.20 & 0.00 & 0.69 & 3 & 3.15 & 1.50 & 0.00160 & 0.00 & & 0.20 & 0.25 & \multicolumn{2}{|l|}{1} \\
\hline & 2500 & 11 & 0.00 & 0.00 & 0.19 & 0.00 & 0.62 & 2 & 0.34 & 0.15 & 0.30000 & 0.10 & & 0.01 & 0 & \multicolumn{2}{|l|}{1} \\
\hline \multirow[t]{2}{*}{2} & 0 & 4 & 1 & 0.00 & 0.21 & 0.00 & 0.75 & 3 & 3.80 & 1.50 & 0.00160 & 0.00 & & 0.20 & 0.19 & \multicolumn{2}{|l|}{1} \\
\hline & 2550 & 11 & 0.00 & 0.00 & 0.20 & 0.00 & 0.69 & 2 & 0.44 & 0.15 & 0.30000 & 0.10 & & 0.04 & 0 & \multicolumn{2}{|l|}{1} \\
\hline \multirow[t]{2}{*}{3} & 0 & 4 & 1 & 0.00 & 0.22 & 0.00 & 0.80 & 3 & 4.40 & 1.50 & 0.00160 & 0.00 & & 0.20 & 0.05 & \multicolumn{2}{|l|}{1} \\
\hline & 1550. & 11 & 0.00 & 0.00 & 0.22 & 0.00 & 0.80 & 2 & 0.58 & 0.15 & 0.30000 & 0.10 & & 0.02 & 0 & \multicolumn{2}{|l|}{1} \\
\hline \multirow[t]{2}{*}{4} & 0 & 4 & 1 & 0.00 & 0.23 & 0.00 & 0.71 & 3 & 4.10 & 1.50 & 0.00160 & 0.00 & & 0.20 & 0.07 & \multicolumn{2}{|l|}{1} \\
\hline & 1550 & 11 & 0.00 & 0.00 & 0.21 & 0.00 & 0.71 & 2 & 0.53 & 0.15 & 0.30000 & 0.10 & & 0.03 & 0 & \multicolumn{2}{|l|}{1} \\
\hline \multirow[t]{3}{*}{5} & 0 & 4 & 1 & 0.00 & 0.25 & 0.00 & 0.80 & 3 & 5.20 & 1.50 & 0.00160 & 0.00 & & 0.20 & 0.05 & 1 & \\
\hline & 1150 & 11 & 0.00 & 0.00 & 0.20 & 0.00 & 0.70 & 2 & 0.43 & 0.15 & 0.30000 & 0.10 & & 0.02 & 0 & 1 & \\
\hline & & & & & & & IMPERV & & & & & & & & & & \\
\hline IRU & IDS & & SLOPE & AREA & & & AREA & UPCOR & & ORCOR & DSCOR & TST & KTS & KSP & $\mathrm{KDC}$ & AIMX & PKFAC \\
\hline 1 & 1 & & 0.30 & 375.0 & & & 5.3 & 1.25 & & 1.25 & 0.00 & 0.0 & 0 & 0 & 0 & 0.00 & 0.00 \\
\hline 2 & 1 & & 0.30 & 730.0 & & & 27.7 & 1.25 & & 1.25 & 0.00 & 0.0 & 0 & 0 & 0 & 0.00 & 0.00 \\
\hline 3 & 1 & & 0.20 & 1349.0 & 132 & & 28.3 & 1.15 & & 1.15 & 0.00 & 0.0 & 0 & 0 & 0 & 0.00 & 0.00 \\
\hline 4 & 1 & & 0.30 & 395.0 & & & 13.4 & 1.00 & & 1.00 & 0.00 & 0.0 & 0 & 0 & 0 & 0.00 & 0.00 \\
\hline 5 & 1 & & 0.20 & 722.0 & & & 16.6 & 1.00 & & 1.00 & 0.00 & 0.0 & 0 & 0 & 0 & 0.00 & 0.00 \\
\hline & & & & --- & & & & & & & & & & & & & \\
\hline TOTAL & & & & 3571.0 & 347 & & 91.4 & & & & & & & & & & \\
\hline
\end{tabular}

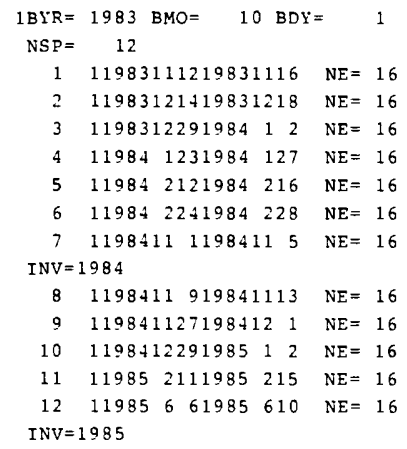

STORMFLOW HYDROGRAPH PARAMETERS FOR EACH HYDROLOGIC RESPONSE UNIT(IRU)

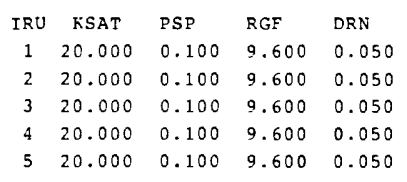




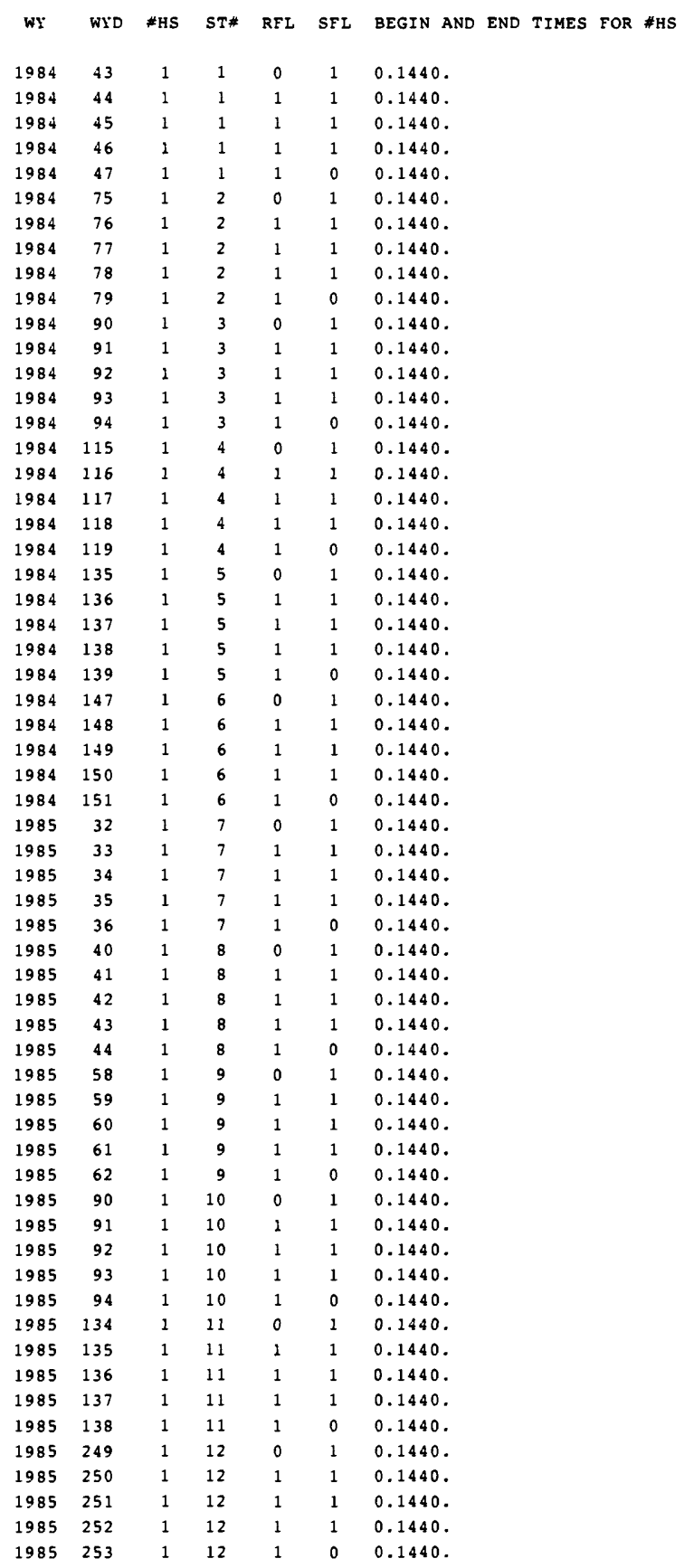


NUMBER OF OVERLAND FLOW PLANE SEGMENTS IS 24 .

\begin{tabular}{|c|c|c|}
\hline $\begin{array}{l}\text { SEGMENT } \\
\text { \# NAME }\end{array}$ & IDS & I RU \\
\hline 1 OF 1 & 1 & 5 \\
\hline 2 OF 2 & 1 & 5 \\
\hline 3 of 3 & 1 & 3 \\
\hline 4 OF 4 & 1 & 3 \\
\hline 5 OF 5 & 1 & 3 \\
\hline 6 OF 6 & 1 & 3 \\
\hline 7 OF 7 & 1 & 3 \\
\hline 8 of 8 & 1 & 3 \\
\hline 9 OF 9 & 1 & 3 \\
\hline 10 of 10 & 1 & 3 \\
\hline 11 OF 11 & 1 & 2 \\
\hline 12 OF 12 & 1 & 1 \\
\hline 13 OF 13 & 1 & 1 \\
\hline 14 OF 14 & 1 & 4 \\
\hline 15 OF 15 & 1 & 4 \\
\hline 16 OF 16 & 1 & 2 \\
\hline 17 OF 17 & 1 & 4 \\
\hline 18 OF 18 & 1 & 1 \\
\hline 19 OF 19 & 1 & 1 \\
\hline 20 OF 20 & 1 & 1 \\
\hline 21 OF 21 & 1 & 3 \\
\hline 22 oF 22 & 1 & 3 \\
\hline 23 oF 23 & 1 & 2 \\
\hline 24 oF 24 & 1 & 2 \\
\hline
\end{tabular}

THEIR CHARACTERISTICS ARE AS FOLLOWS:

\begin{tabular}{|c|c|c|c|c|c|c|c|c|c|c|c|c|c|}
\hline $\begin{array}{l}\text { THRES } \\
\text { DEPTH }\end{array}$ & TYPE & $\begin{array}{l}\text { PRI } \\
\text { IN }\end{array}$ & $\begin{array}{l}\text { NT } \\
\text { OUT }\end{array}$ & NDX & LENGTH & SLOPE & $\begin{array}{l}\text { ROUGH - } \\
\text { NESS }\end{array}$ & PARM 1 & PARM2 & ALPHA & EXPM & $\begin{array}{l}\text { ROUTE } \\
\text { INT. }\end{array}$ & $\begin{array}{l}\text { PRINT } \\
\text { INT. }\end{array}$ \\
\hline 0.0000 & 99 & 0 & 0 & 1 & 689.0 & .0000 & .000 & 0.00 & 0.00 & 0.00 & 0.00 & 5.0 & 30.0 \\
\hline 0.0000 & 99 & 0 & 0 & 1 & 1137.0 & .0000 & .000 & 0.00 & 0.00 & 0.00 & 0.00 & 5.0 & 30.0 \\
\hline 0.0000 & $99^{\circ}$ & 0 & 0 & 1 & 521.0 & .0000 & .000 & 0.00 & 0.00 & 0.00 & 0.00 & 5.0 & 30.0 \\
\hline 0.0000 & 99 & 0 & 0 & 1 & 1159.0 & .0000 & .000 & 0.00 & .00 & 0.00 & 0.00 & 5.0 & 30.0 \\
\hline 0.0000 & 99 & 0 & 0 & 1 & 254.0 & .0000 & .000 & 0.00 & .00 & 0.00 & 0.00 & 5.0 & 30.0 \\
\hline 0.0000 & 99 & 0 & 0 & 1 & 1143.0 & .0000 & .000 & 0.00 & 0.00 & 0.00 & 0.00 & 5.0 & 30.0 \\
\hline 0.0000 & 99 & 0 & 0 & 1 & 379.0 & .0000 & .000 & 0.00 & 0.00 & 0.00 & 0.00 & 5.0 & 30.0 \\
\hline 0.0000 & 99 & 0 & 0 & 1 & 829.0 & .0000 & .000 & 0.00 & 0.00 & 0.00 & 0.00 & 5.0 & 30.0 \\
\hline 0.0000 & 99 & 0 & 0 & 1 & 691.0 & .0000 & .000 & 0.00 & 0.00 & 0.00 & 0.00 & 5.0 & 30.0 \\
\hline 0.0000 & 99 & 0 & 0 & 1 & 624.0 & .0000 & .000 & 0.00 & 0.00 & 0.00 & 0.00 & 5.0 & 30.0 \\
\hline 0.0000 & 99 & 0 & 0 & 1 & 1695.0 & .0000 & .000 & 0.00 & 0.00 & 0.00 & 0.00 & 5.0 & 30.0 \\
\hline 0.0000 & 99 & 0 & 0 & 1 & 875.0 & .0000 & .000 & 0.00 & 0.00 & 0.00 & 0.00 & 5.0 & 30.0 \\
\hline 0.0000 & 99 & 0 & 0 & 1 & 720.0 & .0000 & .000 & 0.00 & 0.00 & 0.00 & 0.00 & 5.0 & 30.0 \\
\hline 0.0000 & 99 & 0 & 0 & 1 & 769.0 & .0000 & .000 & 0.00 & 0.00 & 0.00 & 0.00 & 5.0 & 30.0 \\
\hline 0.0000 & 99 & 0 & 0 & 1 & 545.0 & .0000 & .000 & 0.00 & 0.00 & 0.00 & 0.00 & 5.0 & 30.0 \\
\hline 0.0000 & 99 & 0 & 0 & 1 & 2564.0 & .0000 & .000 & 0.00 & 0.00 & 0.00 & 0.00 & 5.0 & 30.0 \\
\hline 0.0000 & 99 & 0 & 0 & 1 & 844.0 & .0000 & .000 & 0.00 & 0.00 & 0.00 & 0.00 & 5.0 & 30.0 \\
\hline 0.0000 & 99 & 0 & 0 & 1 & 1364.0 & .0000 & .000 & 0.00 & 0.00 & 0.00 & 0.00 & 5.0 & 30.0 \\
\hline 0.0000 & 99 & 0 & 0 & 1 & 1647.0 & .0000 & .000 & 0.00 & 0.00 & 0.00 & 0.00 & 5.0 & 30.0 \\
\hline 0.0000 & 99 & 0 & 0 & 1 & 2168.0 & .0000 & .000 & 0.00 & 0.00 & 0.00 & 0.00 & 5.0 & 30.0 \\
\hline 0.0000 & 99 & 0 & 0 & 1 & 800.0 & .0000 & .000 & 0.00 & 0.00 & 0.00 & 0.00 & 5.0 & 30.0 \\
\hline 0.0000 & 99 & 0 & 0 & 1 & 877.0 & .0000 & .000 & 0.00 & 0.00 & 0.00 & 0.00 & 5.0 & 30.0 \\
\hline 0.0000 & 99 & 0 & 0 & 1 & 1386.0 & .0000 & .000 & 0.00 & 0.00 & 0.00 & 0.00 & 5.0 & 30.0 \\
\hline 0.0000 & 99 & 0 & 0 & 1 & 1348.0 & .0000 & .000 & 0.00 & 0.00 & 0.00 & 0.00 & 5.0 & 30.0 \\
\hline
\end{tabular}

NUMBER OF CHANNEL AND RESERVOIR SEGMENTS IS 14

\begin{tabular}{|c|c|c|c|c|c|c|c|c|c|c|c|c|c|c|c|c|c|c|c|c|}
\hline $\begin{array}{l}\text { SEGMENT } \\
\text { * NAME }\end{array}$ & $\begin{array}{l}\text { UPS } \\
\text { SEG }\end{array}$ & $\begin{array}{l}\text { TREAM } \\
\text { MENTS }\end{array}$ & $\begin{array}{l}\text { ADJA } \\
\text { SEGM }\end{array}$ & $\begin{array}{l}\text { ENT } \\
\text { ENTS }\end{array}$ & $\begin{array}{l}\text { INC. } \\
\text { AREA }\end{array}$ & $\begin{array}{l}\text { CUM. } \\
\text { AREA }\end{array}$ & $\begin{array}{l}\text { THRES } \\
\text { DISC. }\end{array}$ & TYPE & $\begin{array}{l}\text { PRI } \\
\text { IN }\end{array}$ & out & NDX & LENGTH & SLOPE & $\begin{array}{c}\text { ROUGH - } \\
\text { NESS }\end{array}$ & PARM 1 & PARM2 & ALPHA & EXPM & $\begin{array}{l}\text { ROUTE } \\
\text { INT. }\end{array}$ & $\begin{array}{c}\text { PRINT } \\
\text { INT. }\end{array}$ \\
\hline $\mathrm{I} \mathrm{CH} I$ & & & & OF 18 & 107.3 & 107.3 & 0.01 & 1 & 0 & 0 & 2 & 3427.0 & .2000 & .020 & 3.00 & 0.00 & 16.02 & 1.67 & 5.0 & 5.0 \\
\hline $2 \mathrm{CH} 2$ & & & OF 19 & OF 20 & 110.4 & 110.4 & 0.01 & 1 & 0 & 0 & 1 & 1261.0 & .1000 & .040 & 4.00 & 0.00 & 4.67 & 1.67 & 5.0 & 5.0 \\
\hline $3 \mathrm{CH} 3$ & $\mathrm{CH} 2$ & $\mathrm{CHI}$ & & OF 17 & 33.8 & 251.5 & 0.01 & 1 & 0 & 0 & 1 & 1742.0 & .3000 & .020 & 6.00 & 0.00 & 12.36 & 1.67 & 5.0 & 5.0 \\
\hline $4 \mathrm{CHA}$ & & & & OF 16 & 227.6 & 227.6 & 0.01 & 1 & 0 & 0 & 2 & 3867.0 & .1000 & .020 & 3.00 & 0.00 & 11.33 & 1.67 & 5.0 & 5.0 \\
\hline $5 \mathrm{CH} 5$ & & & OF 23 & OF 24 & 220.9 & 220.9 & 0.01 & 1 & 0 & 0 & 2 & 3520.0 & .1000 & .040 & 4.00 & 0.00 & 4.67 & 1.67 & 5.0 & 5.0 \\
\hline $6 \mathrm{CH} 6$ & & & OF 12 & OF 13 & 155.8 & 155.8 & 0.01 & 1 & 0 & 0 & 3 & 4256.0 & .3000 & .040 & 4.00 & 0.00 & 8.10 & 1.67 & 5.0 & 5.0 \\
\hline $7 \mathrm{CH} 7$ & & & OF 11 & & 234.7 & 234.7 & 0.01 & 1 & 0 & 0 & 4 & 6032.0 & .4000 & .020 & 4.00 & 0.00 & 18.70 & 1.67 & 5.0 & 5.0 \\
\hline $8 \mathrm{CH} 8$ & $\mathrm{CH} 4$ & $\mathrm{CH} 3$ & OF 14 & OF 15 & 370.1 & 849.2 & 0.01 & 1 & 0 & 0 & 10 & 12269.0 & .4000 & .060 & 13.00 & 0.00 & 2.84 & 1.67 & 10.0 & 10.0 \\
\hline $9 \mathrm{CH} 9$ & $\mathrm{CH} 5$ & & OF 21 & OF 22 & 244.0 & 464.9 & 0.01 & 1 & 0 & 0 & 4 & 6337.0 & .3000 & .060 & 6.00 & 0.00 & 4.12 & 1.67 & 5.0 & 5.0 \\
\hline $10 \mathrm{CH} 10$ & $\mathrm{CH} 6$ & $\mathrm{CH} 7$ & OF 9 & $O F 10$ & 282.0 & 672.5 & 0.01 & 1 & 0 & 0 & 6 & 9341.0 & .2000 & .060 & 9.00 & 0.00 & 2.57 & 1.67 & 5.0 & 5.0 \\
\hline $11 \mathrm{CH} 11$ & & & OF 7 & OF 8 & 339.9 & 339.9 & 0.01 & 1 & 0 & 0 & 10 & 12256.0 & .1000 & .040 & 5.00 & 0.00 & 4.03 & 1.67 & 5.0 & 5.0 \\
\hline $12 \mathrm{CH} 12$ & $\mathrm{CH} 11$ & $\mathrm{CH} 10$ & OF 5 & OF 6 & 349.1 & 1361.5 & 0.01 & 1 & 0 & 0 & 7 & 10886.0 & .3000 & .070 & 15.00 & 0.00 & 1.92 & 1.67 & 10.0 & 10.0 \\
\hline $13 \mathrm{CH} 13$ & $\mathrm{CH} 12$ & $\mathrm{CHO}$ & OF 3 & OF 4 & 172.5 & 1999.0 & 0.01 & 1 & 0 & 0 & 3 & 4473.0 & .2000 & .070 & 19.00 & 0.00 & 1.34 & 1.67 & 15.0 & 15.0 \\
\hline $14 \mathrm{CH} 14$ & $\mathrm{CH} 13$ & $\mathrm{CH} 8$ & OF 1 & OF2 & 722.5 & 3570.6 & 0.01 & 1 & 0 & 3 & 10 & 17235.0 & .2000 & .070 & 24.00 & 0.00 & 1.14 & 1.67 & 30.0 & 30.0 \\
\hline
\end{tabular}

Basin averaged tıme series written to wdm file: 


\begin{tabular}{rll} 
& DAY & \multicolumn{2}{c}{ OCTOBER } \\
& OBS & PRED \\
1 & 1.00 & 1.21 \\
2 & 1.00 & 1.17 \\
3 & 1.00 & 1.13 \\
4 & 1.00 & 1.10 \\
5 & 0.95 & 1.07 \\
6 & 0.92 & 1.03 \\
7 & 1.00 & 1.00 \\
8 & 1.00 & 0.97 \\
9 & 1.00 & 0.94 \\
10 & 1.00 & 0.92 \\
11 & 0.95 & 0.89 \\
12 & 0.95 & 0.86 \\
13 & 0.95 & 0.84 \\
14 & 0.95 & 0.81 \\
15 & 1.00 & 0.79 \\
16 & 1.00 & 0.76 \\
17 & 1.10 & 0.87 \\
18 & 1.10 & 0.72 \\
19 & 1.10 & 0.95 \\
20 & 1.10 & 0.68 \\
21 & 1.10 & 0.97 \\
22 & 1.60 & 2.91 \\
23 & 1.50 & 0.62 \\
24 & 1.20 & 0.60 \\
25 & 1.10 & 0.58 \\
26 & 1.10 & 0.56 \\
27 & 1.00 & 0.55 \\
28 & 1.00 & 0.53 \\
29 & 1.00 & 0.52 \\
30 & 1.40 & 4.88 \\
31 & 2.40 & 0.49
\end{tabular}

\begin{tabular}{rr}
\multicolumn{2}{c}{ NOVEMBER } \\
OBS & PRED \\
2.20 & 3.83 \\
2.80 & 5.36 \\
32.00 & 28.30 \\
33.00 & 19.22 \\
17.00 & 27.30 \\
24.00 & 49.86 \\
21.00 & 32.61 \\
13.00 & 18.01 \\
20.00 & 27.10 \\
25.00 & 61.23 \\
60.00 & 63.42 \\
44.00 & 61.82 \\
99.00 & 152.53 \\
113.00 & 124.30 \\
69.00 & 48.20 \\
94.00 & 26.64 \\
152.00 & 57.13 \\
141.00 & 58.66 \\
121.00 & 67.62 \\
158.00 & 76.56 \\
104.00 & 70.92 \\
70.00 & 70.55 \\
75.00 & 67.44 \\
196.00 & 129.31 \\
142.00 & 116.76 \\
87.00 & 68.01 \\
60.00 & 64.06 \\
44.00 & 43.88 \\
35.00 & 29.87 \\
40.00 & 51.10 \\
0.00 & 0.00 \\
& \\
12.00
\end{tabular}

\begin{tabular}{rr}
\multicolumn{2}{c}{ DECEMBER } \\
OBS & \multicolumn{1}{c}{ PRED } \\
42.00 & 40.62 \\
34.00 & 30.47 \\
29.00 & 24.53 \\
26.00 & 36.60 \\
38.00 & 61.59 \\
103.00 & 112.94 \\
108.00 & 124.28 \\
119.00 & 92.88 \\
87.00 & 88.22 \\
93.00 & 81.61 \\
82.00 & 52.11 \\
65.00 & 89.10 \\
87.00 & 79.59 \\
120.00 & 95.10 \\
118.00 & 66.34 \\
74.00 & 44.54 \\
51.00 & 34.24 \\
38.00 & 28.73 \\
31.00 & 34.22 \\
26.00 & 28.94 \\
23.00 & 27.45 \\
20.00 & 24.71 \\
20.00 & 23.36 \\
19.00 & 22.37 \\
18.00 & 59.87 \\
19.00 & 52.90 \\
19.00 & 35.63 \\
19.00 & 38.19 \\
95.00 & 124.24 \\
173.00 & 142.20 \\
100.00 & 66.09 \\
& \\
& \\
32 \\
19
\end{tabular}

\begin{tabular}{|c|c|}
\hline \multicolumn{2}{|c|}{ JANUARY } \\
\hline OBS & PRE \\
\hline 65.00 & 40. \\
\hline 51.00 & 47.4 \\
\hline 46.00 & 58. \\
\hline 45.00 & 35. \\
\hline 38.00 & 28.6 \\
\hline 32.00 & 25.2 \\
\hline 28.00 & 23. \\
\hline 25.00 & 22. \\
\hline 23.00 & 21.2 \\
\hline 24.00 & 30.4 \\
\hline 29.00 & 73.1 \\
\hline 26.00 & 55. \\
\hline 23.00 & 34.8 \\
\hline 21.00 & 27.1 \\
\hline 19.00 & 23.5 \\
\hline 17.00 & 21. \\
\hline 17.00 & 20.3 \\
\hline 16.00 & 19.5 \\
\hline 15.00 & 18.7 \\
\hline 14.00 & 23.6 \\
\hline 16.00 & 23.6 \\
\hline 25.00 & 38. \\
\hline 29.00 & 41. \\
\hline 95.00 & 95.5 \\
\hline 85.00 & 82.3 \\
\hline 69.00 & 47.6 \\
\hline 51.00 & 31. \\
\hline 39.00 & 30. \\
\hline 31.00 & 23. \\
\hline 26.00 & 1. \\
\hline 22.00 & 19. \\
\hline
\end{tabular}

\begin{tabular}{rr}
\multicolumn{2}{c}{ FEBRUARY } \\
OBS & PRED \\
20.00 & 18.56 \\
18.00 & 17.83 \\
17.00 & 17.20 \\
16.00 & 16.65 \\
15.00 & 16.33 \\
14.00 & 15.69 \\
13.00 & 15.21 \\
13.00 & 17.19 \\
17.00 & 56.48 \\
34.00 & 71.15 \\
42.00 & 72.88 \\
179.00 & 221.35 \\
380.00 & 347.44 \\
140.00 & 118.29 \\
88.00 & 89.59 \\
78.00 & 73.40 \\
59.00 & 55.38 \\
45.00 & 33.27 \\
35.00 & 29.44 \\
30.00 & 39.60 \\
34.00 & 42.79 \\
35.00 & 32.59 \\
31.00 & 55.01 \\
105.00 & 107.42 \\
131.00 & 97.87 \\
77.00 & 49.79 \\
53.00 & 34.02 \\
40.00 & 27.45 \\
31.00 & 30.53 \\
0.00 & 0.00 \\
0.00 & 0.00
\end{tabular}

\begin{tabular}{ll}
\multicolumn{2}{c}{ MARCH } \\
OBS & PRED \\
29.00 & 33.92 \\
29.00 & 37.75 \\
28.00 & 30.31 \\
25.00 & 25.55 \\
22.00 & 23.11 \\
20.00 & 21.64 \\
18.00 & 20.62 \\
17.00 & 19.83 \\
16.00 & 19.15 \\
15.00 & 18.90 \\
14.00 & 24.66 \\
19.00 & 32.92 \\
34.00 & 93.92 \\
71.00 & 92.36 \\
69.00 & 92.92 \\
75.00 & 97.74 \\
85.00 & 73.41 \\
69.00 & 56.95 \\
65.00 & 42.36 \\
60.00 & 38.13 \\
67.00 & 55.78 \\
67.00 & 42.75 \\
52.00 & 31.18 \\
39.00 & 26.20 \\
33.00 & 41.82 \\
56.00 & 49.04 \\
52.00 & 36.84 \\
39.00 & 33.58 \\
34.00 & 27.45 \\
28.00 & 24.20 \\
25.00 & 22.38 \\
&
\end{tabular}

OBSERVED AND PREDICTED RUNOFF FOR WY 1984

\begin{tabular}{|c|c|c|}
\hline \multirow[t]{2}{*}{ DAY } & \multicolumn{2}{|c|}{ APRIL } \\
\hline & OBS & PRED \\
\hline$I$ & 22.00 & 21.19 \\
\hline 2 & 20.00 & 20.31 \\
\hline 3 & 18.00 & 19.69 \\
\hline 4 & 17.00 & 19.39 \\
\hline 5 & 16.00 & 18.84 \\
\hline 6 & 16.00 & 17.78 \\
\hline 7 & 21.00 & 48.96 \\
\hline 8 & 46.00 & 70.62 \\
\hline 9 & 48.00 & 91.97 \\
\hline 10 & 77.00 & 82.04 \\
\hline 11 & 64.00 & 77.83 \\
\hline 12 & 71.00 & 57.02 \\
\hline 13 & 60.00 & 36.72 \\
\hline 14 & 44.00 & 27.79 \\
\hline 15 & 34.00 & 23.95 \\
\hline 16 & 27.00 & 21.71 \\
\hline 17 & 24.00 & 20.40 \\
\hline 18 & 21.00 & 19.85 \\
\hline 19 & 19.00 & 25.18 \\
\hline 20 & 19.00 & 24.52 \\
\hline $2 I$ & 19.00 & 21.05 \\
\hline 22 & 17.00 & 19.44 \\
\hline 23 & 16.00 & 18.39 \\
\hline 24 & 16.00 & 19.07 \\
\hline 25 & 16.00 & 18.18 \\
\hline 26 & 16.00 & 16.86 \\
\hline 27 & 15.00 & 16.31 \\
\hline 28 & 15.00 & 15.80 \\
\hline 29 & 14.00 & 17.77 \\
\hline 30 & 14.00 & 23.07 \\
\hline 31 & 0.00 & 0.00 \\
\hline
\end{tabular}

\begin{tabular}{cccc}
\multicolumn{2}{c}{ MAY } & \multicolumn{2}{c}{ JUNE } \\
OBS & PRED & OBS & PRED \\
58.00 & 96.52 & 15.00 & 13.41 \\
85.00 & 99.93 & 14.00 & 12.93 \\
76.00 & 55.07 & 13.00 & 13.45 \\
55.00 & 34.21 & 17.00 & 24.77 \\
42.00 & 28.93 & 21.00 & 21.71 \\
34.00 & 22.93 & 50.00 & 48.26 \\
28.00 & 19.96 & 65.00 & 39.91 \\
24.00 & 18.44 & 46.00 & 25.32 \\
23.00 & 20.83 & 36.00 & 21.42 \\
20.00 & 18.14 & 32.00 & 17.25 \\
23.00 & 30.94 & 27.00 & 15.36 \\
26.00 & 24.96 & 24.00 & 14.27 \\
24.00 & 20.41 & 21.00 & 13.54 \\
22.00 & 18.26 & 18.00 & 12.98 \\
20.00 & 16.96 & 17.00 & 12.52 \\
19.00 & 15.97 & 16.00 & 12.11 \\
18.00 & 15.32 & 14.00 & 11.73 \\
16.00 & 14.77 & 13.00 & 11.37 \\
15.00 & 17.62 & 13.00 & 11.02 \\
16.00 & 14.09 & 12.00 & 11.54 \\
15.00 & 13.65 & 13.00 & 10.70 \\
15.00 & 27.72 & 11.00 & 10.06 \\
21.00 & 23.51 & 9.80 & 9.76 \\
20.00 & 18.22 & 9.10 & 9.47 \\
19.00 & 36.44 & 8.20 & 9.19 \\
27.00 & 30.90 & 7.70 & 8.95 \\
27.00 & 21.87 & 7.70 & 8.65 \\
22.00 & 17.90 & 7.60 & 8.39 \\
19.00 & 15.90 & 8.50 & 8.89 \\
17.00 & 14.75 & 7.50 & 7.90 \\
16.00 & 13.98 & 0.00 & 0.00 \\
& & & \\
219 &
\end{tabular}

\begin{tabular}{ll}
\multicolumn{2}{c}{ JULY } \\
OBS & PRED \\
6.90 & 7.66 \\
6.40 & 7.43 \\
6.00 & 7.21 \\
5.40 & 7.00 \\
5.10 & 6.79 \\
5.00 & 6.58 \\
4.80 & 6.39 \\
4.60 & 6.20 \\
4.60 & 6.01 \\
4.40 & 5.83 \\
4.20 & 5.66 \\
4.20 & 5.49 \\
4.20 & 5.33 \\
3.90 & 5.17 \\
3.70 & 5.02 \\
3.50 & 4.87 \\
3.40 & 4.72 \\
3.20 & 4.58 \\
3.20 & 4.44 \\
3.20 & 4.31 \\
3.00 & 4.18 \\
2.90 & 4.06 \\
2.70 & 3.94 \\
2.70 & 3.82 \\
3.10 & 4.27 \\
3.30 & 3.60 \\
2.80 & 3.49 \\
2.80 & 3.38 \\
2.60 & 3.28 \\
2.40 & 3.19 \\
2.20 & 3.09
\end{tabular}

\begin{tabular}{|c|c|}
\hline \multicolumn{2}{|c|}{ AUGUST } \\
\hline OBS & PRED \\
\hline 2.10 & 3.00 \\
\hline 2.10 & 2.91 \\
\hline 2.10 & 2.82 \\
\hline 2.00 & 2.74 \\
\hline 1.90 & 2.66 \\
\hline 1.70 & 2.58 \\
\hline 1.70 & 2.50 \\
\hline 1.60 & 2.43 \\
\hline 1.40 & 2.35 \\
\hline 1.40 & 2.28 \\
\hline 1.30 & 2.22 \\
\hline 1.30 & 2.15 \\
\hline 1.30 & 2.09 \\
\hline 1.30 & 2.02 \\
\hline 1.30 & 1.96 \\
\hline 1.20 & 1.90 \\
\hline 1.10 & 1.85 \\
\hline 1.10 & 1.79 \\
\hline 1.00 & 1.74 \\
\hline 1.00 & 1.69 \\
\hline 1.00 & 1.64 \\
\hline 1.00 & 1.59 \\
\hline 1.00 & 1.54 \\
\hline 1.00 & 1.50 \\
\hline 1.00 & 1.45 \\
\hline 0.99 & 1.41 \\
\hline 0.78 & 1.37 \\
\hline 0.77 & 1.32 \\
\hline 0.77 & 1.29 \\
\hline 0.77 & 1.25 \\
\hline 0.98 & 1.30 \\
\hline
\end{tabular}

SEPTEMBER

OBS PRED

$1.30 \quad 1.14$

0.991 .10

$0.90 \quad 1.07$

$1.70 \quad 4.02$
3.70

$3.70 \quad 2.43$

$3.10 \quad 1.75$

$2.60 \quad 0.95$

$2.00 \quad 0.92$

$1.70 \quad 0.89$

$1.60 \quad 0.87$

$1.50 \quad 0.84$

$1.50 \quad 0.82$

$1.40 \quad 0.79$

$1.20 \quad 0.77$

$1.10 \quad 0.75$

$1.10 \quad 0.72$

$1.10 \quad 0.70$

$1.20 \quad 0.81$

$1.70 \quad 0.66$

$1.70 \quad 0.64$

$1.50 \quad 1.23$

$1.90 \quad 0.60$

$1.90 \quad 0.59$

$1.60 \quad 0.57$

$1.40 \quad 0.55$

$1.10 \quad 0.53$

$0.92 \quad 0.52$

$0.79 \quad 0.50$

$0.77 \quad 0.49$

$0.00 \quad 0.00$ 
OBSERVED AND PREDICTED RUNOFF FOR WY 1985

\begin{tabular}{|c|c|c|c|c|c|c|c|c|c|c|c|c|}
\hline \multirow[t]{2}{*}{ DAY } & \multicolumn{2}{|c|}{ OCTOBER } & \multicolumn{2}{|c|}{ NOVEMBER } & \multicolumn{2}{|c|}{ DECEMBER } & \multicolumn{2}{|c|}{ JANUARY } & \multicolumn{2}{|c|}{ FEBRUARY } & \multicolumn{2}{|c|}{ MARCH } \\
\hline & OBS & PRED & OBS & PRED & $O B S$ & PRED & OBS & PRED & OBS & PRED & OBS & PRED \\
\hline 1 & 0.70 & 0.47 & 26.00 & 63.60 & 94.00 & 61.39 & 53.00 & 41.38 & 9.30 & 23.98 & 16.00 & 12.89 \\
\hline 2 & 0.70 & 0.46 & 546.00 & 556.07 & 64.00 & 54.21 & 40.00 & 31.15 & 11.00 & 18.34 & 15.00 & 16.72 \\
\hline 3 & 0.70 & 0.45 & 399.00 & 374.60 & 47.00 & 35.08 & 32.00 & 31.22 & 11.00 & 15.18 & 15.00 & 27.16 \\
\hline 4 & 0.93 & 1.03 & 128.00 & 131.70 & 35.00 & 29.64 & 27.00 & 25.40 & 9.70 & 14.37 & 18.00 & 27.63 \\
\hline 5 & 1.10 & 0.42 & 61.00 & 56.75 & 28.00 & 26.85 & 24.00 & 23.43 & $9.50^{\circ}$ & 23.15 & 19.00 & 20.54 \\
\hline 6 & 1.10 & 0.41 & 45.00 & 99.64 & 25.00 & 25.18 & 22.00 & 22.16 & 9.30 & 89.37 & 20.00 & 16.75 \\
\hline 7 & 1.10 & 0.40 & 57.00 & 62.43 & 22.00 & 24.02 & 20.00 & 21.22 & 37.00 & 95.03 & 19.00 & 14.84 \\
\hline 8 & 1.50 & 2.45 & 46.00 & 82.34 & 20.00 & 26.10 & 18.00 & 20.46 & 40.00 & 82.70 & 17.00 & 13.92 \\
\hline 9 & 2.80 & 0.48 & 92.00 & 119.69 & 20.00 & 47.05 & 17.00 & 19.78 & 33.00 & 63.75 & 17.00 & 13.05 \\
\hline 10 & 8.30 & 8.35 & 251.00 & 227.84 & 42.00 & 68.06 & 17.00 & 19.15 & 31.00 & 132.55 & 16.00 & 12.51 \\
\hline 11 & 7.10 & 3.26 & 149.00 & 137.20 & 35.00 & 62.93 & 15.00 & 18.56 & 120.00 & 76.63 & 15.00 & 12.06 \\
\hline 12 & 8.50 & 13.40 & 245.00 & 185.40 & 55.00 & 83.90 & 15.00 & 18.00 & 121.00 & 39.86 & 14.00 & 11.66 \\
\hline 13 & 16.00 & 13.75 & 126.00 & 116.64 & 60.00 & 58.66 & 14.00 & 17.46 & 56.00 & 28.38 & 13.00 & 11.29 \\
\hline 14 & 11.00 & 19.23 & 85.00 & 80.88 & 48.00 & 62.55 & 14.00 & 18.25 & 46.00 & 24.60 & 13.00 & 10.94 \\
\hline 15 & 11.00 & 11.62 & 58.00 & 41.11 & 52.00 & 48.25 & 13.00 & 16.78 & 47.00 & 20.60 & 13.00 & 10.61 \\
\hline 16 & 5.60 & 7.07 & 41.00 & 30.19 & 43.00 & 34.58 & 12.00 & 16.27 & 37.00 & 20.09 & 12.00 & 10.29 \\
\hline 17 & 4.10 & 5.37 & 33.00 & 31.00 & 33.00 & 32.72 & 12.00 & 15.77 & 30.00 & 18.21 & 12.00 & 9.98 \\
\hline 18 & 5.50 & 21.99 & 36.00 & 35.65 & 29.00 & 27.88 & 11.00 & 15.29 & 25.00 & 28.23 & 11.00 & 9.68 \\
\hline 19 & 17.00 & 37.00 & 33.00 & 39.45 & 25.00 & 25.41 & 11.00 & 14.84 & 24.00 & 22.82 & 11.00 & 11.34 \\
\hline 20 & 16.00 & 25.52 & 48.00 & 48.20 & 22.00 & 29.30 & 11.00 & 14.39 & 25.00 & 19.37 & 10.00 & 14.94 \\
\hline 21 & 9.50 & 14.22 & 45.00 & 36.88 & 23.00 & 31.65 & 10.00 & 13.96 & 23.00 & 17.55 & 12.00 & 32.72 \\
\hline 22 & 6.50 & 9.68 & 33.00 & 28.48 & 24.00 & 28.64 & 9.60 & 13.54 & 23.00 & 16.45 & 13.00 & 101.79 \\
\hline 23 & 5.00 & 7.60 & 36.00 & 55.82 & 26.00 & 28.64 & 9.50 & 13.14 & 21.00 & 15.89 & 71.00 & 80.82 \\
\hline 24 & 4.30 & 6.55 & 43.00 & 66.12 & 27.00 & 24.99 & 9.20 & 12.75 & 20.00 & 15.14 & 69.00 & 40.69 \\
\hline 25 & 4.10 & 23.64 & 42.00 & 58.88 & 26.00 & 23.21 & 8.80 & 12.37 & 19.00 & 14.62 & 46.00 & 79.85 \\
\hline 26 & 20.00 & 48.85 & 40.00 & 57.22 & 24.00 & 23.46 & 8.80 & 13.31 & 19.00 & 14.15 & 39.00 & 107.50 \\
\hline 27 & 31.00 & 81.66 & 146.00 & 148.90 & 28.00 & 52.46 & 8.40 & 11.99 & 17.00 & 13.71 & 55.00 & 66.96 \\
\hline 28 & 39.00 & 59.19 & 240.00 & 217.38 & 37.00 & 59.40 & 8.40 & 14.42 & 16.00 & 13.42 & 56.00 & 39.41 \\
\hline 29 & 21.00 & 30.51 & 168.00 & 153.04 & 90.00 & 117.88 & 8.40 & 13.62 & 0.00 & 0.00 & 47.00 & 40.30 \\
\hline 30 & 15.00 & 28.12 & 150.00 & 118.54 & 152.00 & 151.00 & 8.20 & 13.54 & 0.00 & 0.00 & 55.00 & 29.31 \\
\hline 31 & 15.00 & 19.54 & 0.00 & 0.00 & 74.00 & 68.92 & 8.30 & 21.88 & 0.00 & 0.00 & 76.00 & 21.87 \\
\hline
\end{tabular}

OBSERVED AND PREDICTED RUNOFF FOR WY 1985

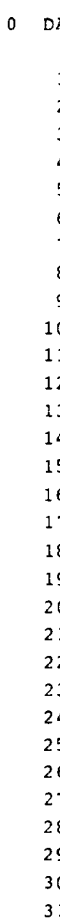

\begin{tabular}{rr}
\multicolumn{2}{c}{ APRIL } \\
OBS & \multicolumn{1}{l}{ PRED } \\
66.00 & 18.49 \\
53.00 & 16.72 \\
44.00 & 15.65 \\
32.00 & 14.91 \\
27.00 & 14.33 \\
23.00 & 13.83 \\
21.00 & 13.38 \\
19.00 & 12.97 \\
18.00 & 12.57 \\
17.00 & 12.19 \\
16.00 & 13.59 \\
15.00 & 11.47 \\
14.00 & 11.13 \\
14.00 & 10.79 \\
14.00 & 10.47 \\
13.00 & 10.16 \\
13.00 & 9.86 \\
12.00 & 12.66 \\
12.00 & 11.76 \\
12.00 & 9.00 \\
12.00 & 10.87 \\
13.00 & 14.45 \\
20.00 & 15.69 \\
19.00 & 14.82 \\
18.00 & 12.21 \\
17.00 & 10.66 \\
16.00 & 9.92 \\
15.00 & 9.59 \\
14.00 & 9.09 \\
14.00 & 8.77 \\
0.00 & 0.00
\end{tabular}

\begin{tabular}{cc}
\multicolumn{2}{c}{ MAY } \\
OBS & PRED \\
13.00 & 8.48 \\
12.00 & 8.31 \\
12.00 & 9.18 \\
12.00 & 7.83 \\
11.00 & 7.49 \\
11.00 & 7.26 \\
10.00 & 7.04 \\
9.80 & 6.83 \\
9.40 & 6.63 \\
9.10 & 6.51 \\
9.00 & 6.24 \\
8.70 & 6.05 \\
8.10 & 5.87 \\
8.10 & 5.76 \\
8.00 & 5.53 \\
7.50 & 5.36 \\
7.10 & 5.20 \\
7.10 & 5.05 \\
6.80 & 4.90 \\
6.80 & 4.75 \\
6.70 & 4.61 \\
6.40 & 4.47 \\
5.90 & 4.34 \\
5.90 & 4.21 \\
5.90 & 4.09 \\
5.80 & 3.96 \\
5.60 & 3.85 \\
6.40 & 6.07 \\
6.20 & 3.62 \\
5.80 & 3.51 \\
7.30 & 4.14
\end{tabular}

\begin{tabular}{rr}
\multicolumn{2}{c}{ JUNE } \\
OBS & \multicolumn{1}{c}{ PRED } \\
6.40 & 3.31 \\
5.80 & 3.21 \\
5.30 & 3.29 \\
5.60 & 3.05 \\
5.60 & 4.23 \\
89.00 & 72.77 \\
189.00 & 245.66 \\
78.00 & 90.99 \\
41.00 & 36.52 \\
28.00 & 19.69 \\
21.00 & 24.76 \\
18.00 & 11.32 \\
15.00 & 9.23 \\
13.00 & 8.15 \\
12.00 & 7.52 \\
11.00 & 7.11 \\
9.70 & 6.80 \\
8.70 & 6.55 \\
8.20 & 6.33 \\
7.60 & 6.13 \\
7.30 & 5.94 \\
7.00 & 5.76 \\
6.70 & 5.58 \\
6.50 & 5.42 \\
6.40 & 5.25 \\
5.70 & 5.10 \\
5.60 & 4.95 \\
5.30 & 4.80 \\
5.10 & 4.65 \\
5.00 & 4.52 \\
0.00 & 0.00 \\
&
\end{tabular}

\begin{tabular}{lc}
\multicolumn{2}{c}{ JULY } \\
OBS & PRED \\
4.80 & 4.38 \\
4.50 & 4.25 \\
4.20 & 4.12 \\
3.90 & 4.00 \\
3.70 & 3.88 \\
3.70 & 3.77 \\
3.50 & 3.65 \\
3.50 & 3.54 \\
3.40 & 3.44 \\
3.00 & 3.34 \\
3.00 & 3.24 \\
3.00 & 3.14 \\
2.80 & 3.05 \\
2.80 & 2.96 \\
2.70 & 2.87 \\
2.70 & 2.78 \\
2.70 & 2.70 \\
2.50 & 2.62 \\
2.40 & 2.54 \\
2.20 & 2.47 \\
2.20 & 2.39 \\
2.20 & 2.32 \\
2.20 & 2.25 \\
2.10 & 2.18 \\
2.00 & 2.12 \\
2.00 & 2.06 \\
1.70 & 2.00 \\
1.70 & 1.94 \\
1.70 & 1.88 \\
2.60 & 1.82 \\
3.60 & 1.77 \\
& \\
2.70 \\
2.00
\end{tabular}

\begin{tabular}{lc}
\multicolumn{2}{c}{ AUGUST } \\
OBS & PRED \\
3.00 & 1.7 \\
2.70 & 1.6 \\
2.30 & 1.6 \\
2.10 & 1.5 \\
2.00 & 1.5 \\
1.90 & 1.4 \\
1.70 & 1.4 \\
1.80 & 1.39
\end{tabular}

SEPTEMBER

$\begin{array}{lr}\text { OBS } & \text { PRED } \\ 0.84 & 0.67\end{array}$

$0.98 \quad 0.65$

0.920 .63

0.920 .61

$\begin{array}{ll}0.92 & 0.61 \\ 0.93 & 0.59\end{array}$

$1.70 \quad 0.58$

$1.50 \quad 0.56$

$\begin{array}{ll}1.50 & 0.56 \\ 1.20 & 0.54\end{array}$

$\begin{array}{llll}1.90 & 1.35 & 1.10 & 0.53\end{array}$

$\begin{array}{llll}1.70 & 1.31 & 1.20 & 0.51\end{array}$

$\begin{array}{llll}1.70 & 1.27 & 1.20 & 0.50\end{array}$

$\begin{array}{llll}1.60 & 1.23 & 1.80 & 3.21\end{array}$

$\begin{array}{llll}1.60 & 1.19 & 2.70 & 0.47\end{array}$

$1.50 \quad 1.16 \quad 1.90 \quad 1.89$

$\begin{array}{llll}1.40 & 1.12 & 2.00 & 0.44\end{array}$

$\begin{array}{llll}1.40 & 1.09 & 2.00 & 0.86\end{array}$

$\begin{array}{llll}1.30 & 1.06 & 2.70 & 1.59\end{array}$

$\begin{array}{llll}1.30 & 1.03 & 2.70 & 0.40\end{array}$

$\begin{array}{llll}1.30 & 0.99 & 1.80 & 0.39\end{array}$

$\begin{array}{llll}1.30 & 0.97 & 1.60 & 0.39\end{array}$

$\begin{array}{llll}1.20 & 0.94 & 1.40 & 0.37\end{array}$

$\begin{array}{llll}1.20 & 0.91 & 1.30 & 0.36\end{array}$

$\begin{array}{llll}1.20 & 0.88 & 1.30 & 0.35\end{array}$

$\begin{array}{llll}1.20 & 0.86 & 1.20 & 0.33\end{array}$

$\begin{array}{llll}1.20 & 0.83 & 1.10 & 0.32\end{array}$

$\begin{array}{llll}1.20 & 0.81 & 1.10 & 0.32\end{array}$

$\begin{array}{llll}1.00 & 0.78 & 1.00 & 0.31\end{array}$

$\begin{array}{llll}0.92 & 0.76 & 1.00 & 0.30\end{array}$

$\begin{array}{llll}0.89 & 0.74 & 1.00 & 0.29\end{array}$

$0.84 \quad 0.71 \quad 1.00 \quad 0.28$

O-PPT N-PPT XINT POTET ACTET

SMELT

IRLOS P-ROFF TO-ROFF O-ROFF

ANNUAL SUMMARY 1985 OBSERVED PRECIP $=79.10$ POTENTIAL ET $=31.70$ PREDICTED RUNOFF(IN) $=61.50 \quad$ OBSERVED RUNOFF(IN) $=\quad 59.71$ NET PRECIP $=84.12$ ACTUAL ET $=10.80$

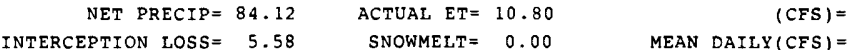
$(C F S)=8974.71$ 25.32 MEAN DAILY (CFS) =

24.59

GW IN $=7.50 \quad$ SSR IN $=63.20 \quad$ SSR TO $\mathrm{GW}=28.20$ SURFACE RO $=4.25 \quad$ SSR FLOW $=33.38 \quad$ GW FLOW $=23.85 \quad$ GW SINK= 11.72 

SUMMARY STATISTICS FOR WATER YEAR 1984

\begin{tabular}{|c|c|c|c|c|c|c|c|c|}
\hline & & \multicolumn{2}{|c|}{$\begin{array}{l}\text { MEAN RUNOFF } \\
\text { (CFS) }\end{array}$} & \multicolumn{2}{|c|}{$\begin{array}{l}\text { TOTAL RUNOFF } \\
\text { (CFS DAYS) }\end{array}$} & \multicolumn{2}{|c|}{$\begin{array}{c}\text { \# OF } \\
\text { RESIDUALS }\end{array}$} & \multirow[t]{2}{*}{$\begin{array}{l}\text { \# OF } \\
\text { RUNS }\end{array}$} \\
\hline 0 & $\mathrm{OCT}$ & $\begin{array}{l}\text { OBSV. } \\
1.112\end{array}$ & $\begin{array}{l}\text { PRED. } \\
1.030\end{array}$ & $\begin{array}{l}\text { OBSV. } \\
34.470\end{array}$ & $\begin{array}{r}\text { PRED. } \\
31.920\end{array}$ & $\begin{array}{r}+ \\
22\end{array}$ & -.11 & \\
\hline 0 & Nov & 69.800 & 57.387 & 2094.000 & 1721.596 & 15 & 15 & 9 \\
\hline 0 & DEC & 61.161 & 60.117 & 1896.000 & 1863.627 & 14 & 17 & 9 \\
\hline 0 & JAN & 34.258 & 35.670 & 1062.000 & 1105.763 & 15 & 16 & 5 \\
\hline 0 & $F E B$ & 61.724 & 62.772 & 1790.000 & 1820.398 & 14 & 15 & 9 \\
\hline 0 & MAR & 41.032 & 41.528 & 1272.000 & 1287.379 & 14 & 17 & 4 \\
\hline 0 & APR & 28.067 & 31.055 & 842.000 & 931.653 & 8 & 22 & 4 \\
\hline 0 & MAY & 27.806 & 27.068 & 862.000 & 839.102 & 23 & 8 & 10 \\
\hline 0 & JUN & 19.137 & 15.226 & 574.100 & 456.785 & 20 & 10 & 4 \\
\hline 0 & JUL & 3.884 & 5.064 & 120.400 & 156.983 & 0 & 31 & 1 \\
\hline 0 & AUG & 1.289 & 1.978 & 39.960 & 61.326 & 0 & 31 & 1 \\
\hline 0 & SEP & 1.542 & 0.980 & 46.270 & 29.413 & 27 & 3 & 3 \\
\hline 0 & & & & & & & & \\
\hline & YEAR & 29.052 & 28.158 & 10633.199 & 10305.945 & 172 & 194 & 58 \\
\hline 0 & $\begin{array}{r}\text { MES-MFN } \\
\text { SEASON }\end{array}$ & 29.052 & 28.158 & 10633.199 & 10305.945 & 172 & 194 & 58 \\
\hline
\end{tabular}

0 RESIDUAL = OBSERVED - PREDICTED

MFS-MFN SEASON IS OCT TO SEP

1

SUMMARY STATISTICS FOR WATER YEAR 1985

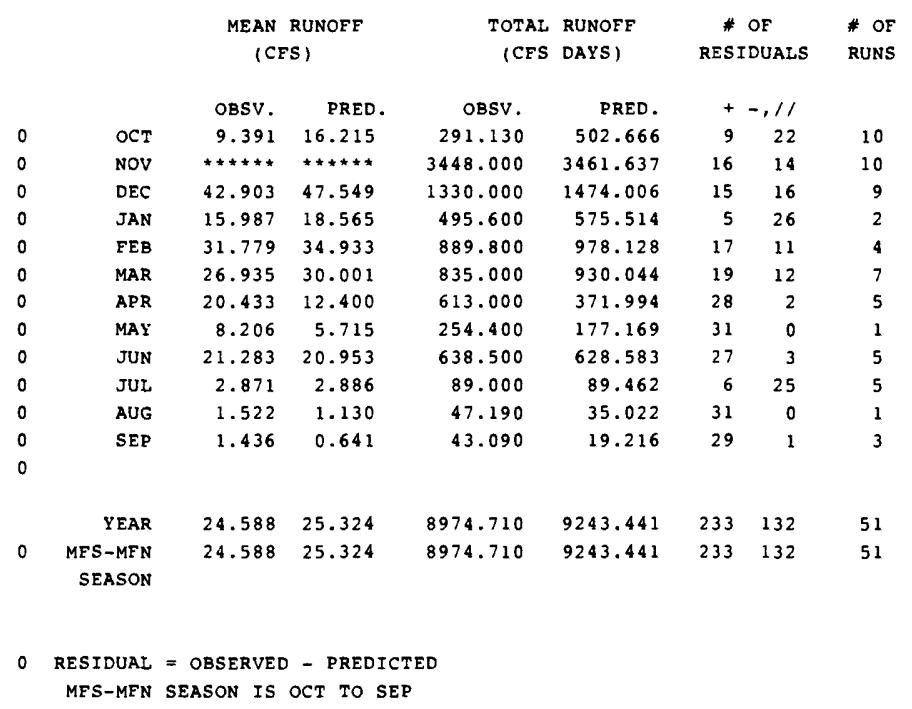




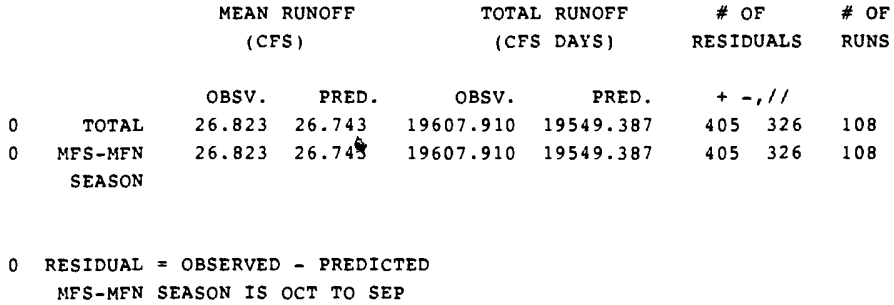

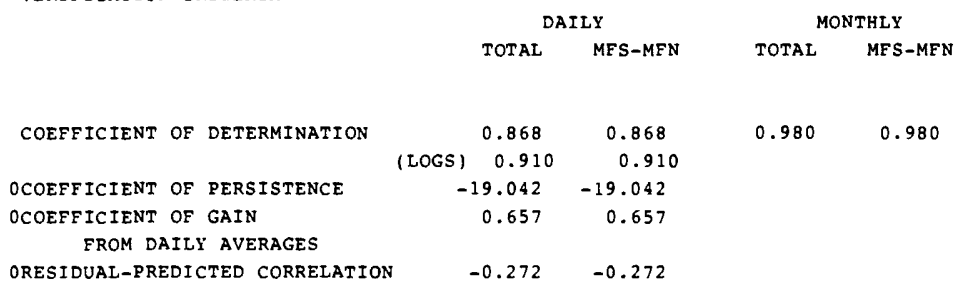

\begin{tabular}{|c|c|c|c|c|c|c|}
\hline \multicolumn{7}{|c|}{ ERROR SUMMARY (MFS-MFN PERIOD) } \\
\hline & \multicolumn{2}{|c|}{ ERRORS } & \multicolumn{2}{|c|}{ ABSOLUTE ERRORS } & SQUARED & ERRORS \\
\hline & No LOG & LOG & NO LOG & LOG & NO LOG & LOG \\
\hline SUM & 58.52 & 16.17 & 5845.61 & 207.93 & 184439.47 & 104.75 \\
\hline MEAN & 0.08 & 0.02 & 8.00 & 0.28 & 252.31 & 0.14 \\
\hline PERCENT & 0.30 & & 29.81 & & 59.22 & \\
\hline
\end{tabular}

\begin{tabular}{|c|c|c|c|c|c|c|c|c|}
\hline & & & ERROR SUM & MARY (TOTAL & PER & & & \\
\hline & & ERROR & & $A B$ & soLut & ERRORS & SQUARE & ERRORS \\
\hline & No & LOG & LOG & No & LOG & LOG & NO LOG & LOG \\
\hline sum & & .52 & 6.17 & 5845 & .61 & 207.93 & 184439.47 & 104.75 \\
\hline MEAN & & 1.08 & 0.02 & & .00 & 0.28 & 252.31 & 0.14 \\
\hline PERCENT & & .30 & & & .81 & & 59.22 & \\
\hline ISTORM & $\begin{array}{l}\text { PREDICTED } \\
\text { VOLUME } \\
\text { (INCHES) }\end{array}$ & $\begin{array}{l}\text { ROUTED } \\
\text { OUTELOW } \\
\text { (INCHES) }\end{array}$ & $\begin{array}{l}\text { OBSERVED } \\
\text { OUTELOW } \\
\text { (INCHES) }\end{array}$ & $\begin{array}{l}\text { PREDICTED } \\
\text { PEAK } \\
\text { (CFS) }\end{array}$ & $\begin{array}{l}\text { OBS } \\
\text { PE } \\
\text { IC }\end{array}$ & $\begin{array}{l}\text { VED } \\
k \\
\text { b) }\end{array}$ & & \\
\hline 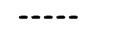 & -.non. & - & - & - & $\ldots$ & -.- & & \\
\hline 1 & 2.77 & 2.76 & 2.80 & 253.57 & 185 & & & \\
\hline 2 & 1.79 & 1.79 & 2.84 & 118.92 & 164 & & & \\
\hline 3 & 2.83 & 2.80 & 3.25 & 212.10 & 348 & & & \\
\hline 4 & 2.00 & 1.99 & 2.20 & 124.40 & 120 & & & \\
\hline 5 & 5.71 & 5.67 & 5.33 & 478.00 & 435 & & & \\
\hline 6 & 2.11 & 2.11 & 2.71 & 165.08 & 174 & & & \\
\hline 7 & 7.95 & 7.88 & 6.43 & 659.70 & 652 & & & \\
\hline 8 & 5.29 & 5.24 & 5.46 & 310.41 & 318 & & & \\
\hline 9 & 4.70 & 4.66 & 5.32 & 259.29 & 264 & & & \\
\hline 10 & 2.75 & 2.73 & 2.72 & 239.62 & 232 & & & \\
\hline 11 & 1.24 & 1.27 & 2.60 & 123.77 & 255 & & & \\
\hline 12 & 3.15 & 3.10 & 2.83 & 360.99 & 289 & & & \\
\hline MEAN & 3.52 & 3.50 & 3.71 & 275.49 & 286 & & & \\
\hline LOGS & 1.12 & 1.12 & 1.24 & 5.48 & & & & \\
\hline
\end{tabular}


STORM VOLUME ERROR SUMMARY

\begin{tabular}{rrrrr} 
& \multicolumn{2}{c}{ ABS VALUE OBF FNC } & \multicolumn{2}{c}{ SUM OF SQUARES OBF FNC } \\
SUM & NO LOG & LOG & NO LOG & LOG \\
MEAN & 6.70 & 2.25 & 6.52 & 0.93 \\
PERCENT & 0.56 & 0.19 & 0.54 & 0.08 \\
& 15.05 & & 19.88 &
\end{tabular}

STORM PEAK ERROR SUMMARY

\begin{tabular}{rrrrr} 
& \multicolumn{2}{c}{ ABS VALUE OBF FNC } & \multicolumn{2}{c}{ SUM OF SQUARES OBF FNC } \\
SUM & NO LOG & LOG & NO LOG & LOG \\
MEAN & 536.69 & 2.35 & 49750.20 & 1.03 \\
PERCENT & 44.72 & 0.20 & 4145.85 & 0.09 \\
& 15.62 & & 22.49 &
\end{tabular}

discharge time series written to dsn:

$\begin{array}{rlllllllll}0 & 0 & 0 & 0 & 0 & 0 & 0 & 0 & 0 & 0 \\ 0 & 0 & 0 & 0 & 0 & 0 & 0 & 0 & 0 & 0 \\ 0 & 0 & 0 & 0 & 0 & 0 & 0 & 0 & 0 & 0 \\ 0 & 0 & 0 & 0 & 0 & 0 & 0 & 31 & & \end{array}$

sediment time series written to dsn:

$\begin{array}{llllllllll}0 & 0 & 0 & 0 & 0 & 0 & 0 & 0 & 0 & 0 \\ 0 & 0 & 0 & 0 & 0 & 0 & 0 & 0 & 0 & 0 \\ 0 & 0 & 0 & 0 & 0 & 0 & 0 & 0 & 0 & 0 \\ 0 & 0 & 0 & 0 & 0 & 0 & 0 & 32 & & \\ \text { CH14 out } & 0 & 31 & & & & & & \\ \text { Next storm } & & & & & & & \\ \text { Next storm } & & & & & & \\ \text { Next storm } & \\ \text { Next storm } \\ \text { Next storm } \\ \text { Next storm } \\ \text { Next storm } \\ \text { Next storm } \\ \text { Next storm } \\ \text { Next storm } \\ \text { Next storm } \\ \text { Next storm } \\ \text { Finished saving time series to wdm file }\end{array}$

